\title{
Moina macrocopa (Straus, 1820): a species complex of a common Cladocera, highlighted by morphology and DNA barcodes
}

\author{
Lucía Montoliu-Elena ${ }^{1,2}$, Manuel Elías-Gutiérrez ${ }^{2, *}$ and Marcelo Silva-Briano ${ }^{3}$ \\ ${ }^{1}$ Posgrado en Ciencias del Mar y Limnología, Universidad Nacional Autónoma de México; Av. Ciudad Univer- \\ sitaria 3000, Coyoacán 04510, Ciudad de México, México. \\ 2 El Colegio de la Frontera Sur, Chetumal unit, Av. Centenario Km 5.5, Chetumal 07714, Quintana Roo, \\ México. \\ ${ }^{3}$ Laboratorio No.1, Ecología. Edificio 202. Centro de Ciencias Básicas. Av. Universidad No. 940 Ciudad \\ Universitaria. Universidad Autónoma de Aguascalientes, Aguascalientes 20131, México. \\ * Corresponding author: melias@ecosur.mx
}

Received: 15/02/18 Accepted: 29/10/18

\begin{abstract}
Moina macrocopa (Straus, 1820): a species complex of a common Cladocera, highlighted by morphology and DNA barcodes

Freshwater microcrustaceans are one of the most diverse and understudied groups of the animal kingdom and are best described by the use of an integrative taxonomic approach, including morphological, molecular and geographical data. In this study, we used three different types of characters, including detailed morphological analyses, DNA barcodes (COI gene) and geographical distribution to study the Old-World clade Moina macrocopa (Straus, 1820), here considered as M. macrocopa s.l. and the American clade Moina macrocopa americana Goulden, 1968. Results have indicated that these clades are different species and not subspecies, while Moina macrocopa s.l. is suggested to be species complex with a minimum of three different clades.
\end{abstract}

Key words: zooplankton, Moina macrocopa, cryptic species, integrative taxonomy, DNA Barcodes, COI

\section{RESUMEN}

Moina macrocopa (Straus, 1820): complejo de especies en un cladócero común, destacado por su morfología y códigos de barras de $A D N$

Los microcrustáceos de aguas continentales son uno de los grupos más diverso y menos estudiado del reino animal. Un enfoque integrativo, que incluya al menos, datos morfológicos, moleculares y geográficos es esencial para delimitar las especies de estos invertebrados, como es el caso del complejo Moina macrocopa. En este estudio, utilizamos tres tipos de caracteres: morfológicos, genéticos (códigos de barras del ADN) y geográficos, para demostrar que Moina macrocopa (Straus, 1820), el clado del Viejo Mundo, considerado aquí como M. macrocopa s.l., y Moina macrocopa americana Goulden, 1968, el clado americano, son especies distintas, no subespecies. Además, confirmamos que Moina macrocopa s.l. es un complejo de especies, formado por un mínimo de 3 clados diferentes.

Palabras clave: zooplancton, Moina macrocopa, especies crípticas, taxonomía integrativa, Códigos de Barras de la Vida, COI 


\section{INTRODUCTION}

Moina is one of the most confusing genera of cladocerans and is the second most diverse Anomopod (Goulden, 1968; Elías-Gutiérrez et al., 2008a; Nédli et al., 2014; Bekker et al., 2016).

This cladoceran has been mainly recorded in water bodies severely eutrophicated under heavy anthropogenic influences (sewage, fertilizers). It is a species whose populations play a key role in food webs of epicontinental aquatic environments (Vignatti et al., 2013) and it is of economic importance due to its use as live food for fishes (Valdivia-Villar, 1988; Elías-Gutiérrez, 1995) and as bioindicator of water quality (Nandini et al., 2004).

Moina macrocopa macrocopa (Straus, 1820) was drawn for the first time by Joblot in 1754 who referred to it as "pou aquatique" (water flea) (Joblot, 1754). 65 years later, in 1819, the French zoologist Hercule Eugène Straus-Durckheim illustrated this species again, and finally, in 1820, he described it as Daphnia macrocopus (Straus, 1820). After his publication, numerous synonyms have been described due to the lack of details in his description and illustration (Straus, 1819, 1820; Goulden, 1968) and it was not recognized as its currently valid name Moina macrocopa until the early 1900's (Goulden, 1968).

Goulden (1968) in his revision of the genus, proposed two subspecies: Moina macrocopa macrocopa (Straus, 1820) as the typical form restricted to the Old World, and described Moina macrocopa americana, type locality Cheyenne Bottoms Waterfowl Refuge in Barton County, Kansas, limited to USA. Several morphological differences have been found between both subspecies, being the first clues of the non-cosmopolitanism of Cladocera suggested later by Frey $(1980,1987)$ and afterward presented by Bekker et al. (2016; Fig. 2).

Arevalo (1920), cited Moina macrocopa macrocopa (Straus, 1820) for the first time in the Iberian Peninsula, from Gandía (Comunidad Valenciana, Spain) under the name Moina rectrirostris var. casañi. Then, Alonso (1996) on his revision of the Iberian Fauna, described and illustrated Moina macrocopa macrocopa (Straus, 1820) from Albufera de Valencia (Comunidad
Valenciana, Spain), being the only place in the Iberian Peninsula where he found this species. This subspecies was then reported in many localities all over the world in: Europe, Asia, South America and North Africa (Goulden, 1968; Elías-Gutiérrez \& Zamuriano-Claros, 1994; Paggi, 1997; Petrusek, 2002; Mangas-Ramírez et al., 2004; Elmoor-Loureiro et al., 2010; Kotov et al., 2012; Rietzler et al., 2014; Ghaouaci et al., 2018).

In the case of the American subspecies, Moina macrocopa americana Goulden, 1968, thought its distribution restricted to the United States but in 2011, it was recorded from Canada (Manitoba) (Jeffery et al., 2011), and previously it was found in central Mexico (Elías-Gutiérrez, 1995; Elías-Gutiérrez et al., 2008b; Prosser et al., 2013) expanding its distribution area all over North America.

Due to the ubiquity, small size, phenotypic plasticity, genetic variability, cryptic taxa and lack of taxonomical identification keys for many parts of the world (Goulden, 1968), an integrative approach must be made to delimitate with accuracy the species from this complex. The use of DNA barcoding (cytochrome oxidase c subunit 1 - COI gene as a fast, reliable and cost-effective tool to delimit the animal species (Hebert et al., 2003a) has led to the discovery of cryptic diversity among invertebrates (Mills et al., 2016; Chertoprud et al., 2017 and Lavinia et al., 2017) and other animal groups (i.e. Álvarez-Castañeda et al., 2012; Lima et al., 2017). In this regard, Bekker et al., (2016) have demonstrated with DNA barcodes, a possible high cryptic diversity of the Old World Moina macrocopa (Straus, 1820), though they only presented a tree with differences among Eurasian clades without discussing it. For this reason, we hereby designate all specimens from the Old World as $M$. macrocopa s.l. (sensu lato).

Other authors proved the value of DNA Barcoding for the early detection of exotic species in many groups (Valdez-Moreno et al., 2012; Gutiérrez-Aguirre et al., 2014; Montoliu et al., 2015). Finally, the biogeographical signal of this gene shows a high correspondence between haplotypes and restricted distributions permitting us to delimitate with accuracy the species (Mills et al., 2016). 
In this work, we studied the Moina macroco$p a$ species complex using morphological, genetical (DNA Barcodes) and biogeographical analyses to re-describe Moina macrocopa americana Goulden, 1968 and demonstrate that it is a distinct species, not a subspecies, of Moina macrocopa s.l.

\section{MATERIAL AND METHODS}

\section{Sampling}

Specimens of Moina macrocopa s.l. and Moina macrocopa americana Goulden, 1968 were collected with a plankton net with mesh size of 45 $\mu \mathrm{m}$, and a hand net with mesh size of $90 \mu \mathrm{m}$, from Albufera Lake in Valencia (Spain), a small pond in Calderitas (Quintana Roo, Mexico), Texcoco Lake (Mexico State, Mexico), Los Gringos dam and Niagara dam (Aguascalientes, Mexico) (see table S1, available at http://www.limnetica.net/ en/limnetica). All samples were preserved in $96 \%$ alcohol (non-denaturated) following the procedure suggested by Prosser et al. (2013) and stored in the freezer for a minimum duration of 72 $\mathrm{h}$, to preserve the DNA.

\section{Morphological observations}

Specimens were sorted from the ethanol samples under a stereomicroscope and placed in a drop of glycerol. Ten females and males of each population were dissected. Whole animals and dissected sections were examined and measured under a compound microscope, and identified following the descriptions of several authors, i.e., Straus (1820), Goulden (1968), Alonso (1996), Paggi (1997), Elías-Gutiérrez et al. (2008b). Five specimens of each sex and subspecies were prepared for Scanning Electron Microscopy (SEM) for the observation of microcharacters with a JEOL microscope Model JSM6010 Plus in Chetumal Unit of ECOSUR (Mexico) at $10 \mathrm{KV}$ and a JEOL microscope Model LB5900 at $12 \mathrm{KV}$ in the Autonomous University of Aguascalientes (Mexico).

Mexican specimens were deposited in the reference collection of El Colegio de la Frontera Sur (ECOSUR) Chetumal unit, in Mexico, and
Spain, in the collection of Freshwater zooplankton at the Institut Cavanilles de Biodiversitat i Biologia Evolutiva (University of Valencia, Spain).

\section{Molecular markers}

COI gene was selected as a molecular marker for this study for its fast-evolving mitochondrial protein-coding genes, which reflect the evolutionary history of invertebrate populations (Audzijonyte \& Väinölä, 2006). Also, it is a useful tool to discriminate cladoceran species, becoming a standard for species-level identification (Machida et al., 2004; Dasmahapatra et al., 2010; Gutiérrez-Aguirre et al., 2014; Montoliu et al., 2015), and a model in species delimitation (Puillandre et al., 2012).

\section{DNA isolation, PCR amplification, and sequencing}

DNA was extracted using AcroPrep 96 Filter Plate $3 \mu \mathrm{m} \mathrm{GF} / 0.2 \mu \mathrm{m}$ BioInert (Pall Corporation, Port Washington, NY, USA) according to the manufacturer's instructions. The Polymerase Chain Reaction (PCR) was used to amplify approximately $600-658 \mathrm{bp}$ of the COI gene using Zplank primers suggested by Prosser et al. (2013). The $12.5 \mu 1$ PCR reaction mixes included $6.25 \mu 1$ of $10 \%$ trehalose stabilizer, $2 \mu 1$ of ultrapure water, $1.25 \mu 1$ of 10X PCR buffer, 0.625 of $\mathrm{MgCl} 2(50 \mathrm{mM}), 0.125 \mu \mathrm{l}$ of each primer $(0.01$ $\mathrm{mM}), 0.0625 \mu \mathrm{l}$ of each dNTP mix $(0.05 \mathrm{mM})$, $0.625 \mu 1$ of Taq polymerase $(5 \mathrm{U} / \mu 1)$ (New England Biolabs or Invitrogen), and $2.0 \mu \mathrm{l}$ of DNA template. Thermocycler program was as follows: $94{ }^{\circ} \mathrm{C}$ for 1 minute, 5 cycles of $94{ }^{\circ} \mathrm{C}$ for 40 seconds, $45{ }^{\circ} \mathrm{C}$ for 40 seconds, $72{ }^{\circ} \mathrm{C}$ for 1 minute, followed by 35 cycles of denaturation at $94{ }^{\circ} \mathrm{C}$ for 40 seconds, annealing at $51^{\circ} \mathrm{C}$ for 40 seconds, elongation at $72{ }^{\circ} \mathrm{C}$ for 1 minute, and a final extension at $72^{\circ} \mathrm{C}$ for 5 minutes, with a final hold at $4{ }^{\circ} \mathrm{C}$. The PCR products were visualized on a $2 \%$ agarose gels (E-gel ${ }^{\circledR} 96$ system, Invitrogen Inc.). Amplicons were bidirectionally sequenced using BigDye Terminator Cycle Sequencing Kit (v3.1) on an ABI 3730XL DNA Analyzer. The forward and the reverse sequences were assembled, edited and aligned using Codon- 
Code Aligner v. 5.0.1 (CodonCode Corporation, USA) and tested in MEGA6 (V 6.0) (Tamura et al., 2013) to verify that they were free of stop codons and gaps.

We prepared a dataset under the name DS-MMACRO with all specimens and sequence information in the Barcode of Life (BOLD). It includes all sequences generated in this study and all public sequences available and previously published, including those in GenBank.

\section{Sequence analysis}

COI sequences obtained in this study were combined with those for M. macrocopa s.l. and $M$. macrocopa americana Goulden, 1968 available in GenBank and BOLD (see table S1, available at http://www.limnetica.net/en/limnetica) to corroborate the identity of our sequences and to gain a better understanding of the geographical genetic diversity for both subspecies.

COI sequences were aligned with BOLD aligner and the non-overlapping sequence regions at the $5^{\prime}$ - and $3^{\prime}$-ends were trimmed.

As the first approach, genetic divergence between groups was calculated using K2P model (Kimura, 1980) with pairwise deletion of gaps and missing data.

To perform the Maximum Likelihood (ML) tree distances, a best-fitting model of nucleotide substitution was selected in MEGA6, based on the likelihood for 24 different nucleotide substitution models and the Akaike information criterion (Posada \& Buckley, 2004). The best model was Tamura 3-parameters with a specific fraction of sites evolutionarily invariable (T92+I) (Tamura, 1992). The analysis was performed using 500 bootstraps, and partial deletion of gaps and missing data. Finally, a single sequence of Moina $\mathrm{cf}$. micrura 2 from Mexico was used as an outgroup, (See table S1, available at http://www.limnetica. net/en/limnetica). Monophyly was confirmed with the web service "Monophilizer" (Mutanen et al., 2016).

\section{Species delimitation analysis}

Molecular operational taxonomic units (MOTU's) have frequently been used to infer putative species boundaries where morphological identifications are difficult (Ashfaq et al., 2015). To assess the presence of cryptic taxa, we implemented four different clustering algorithms to assign the COI sequences from M. macrocopa s.l. and $M$. macrocopa americana complex species to MOTU's: the Refine Single Linkage algorithm (RESL, Barcode Index Number, or BIN) (Ratnasingham \& Hebert, 2013), Automatic Barcode Gap Discovery (ABGD) (Puillandre et al., 2012), multi-rate Poisson tree processes (mPTP) (Triantafyllidis et al., 2011) and statistical parsimony networks (TCS) (Clement et al., 2002).

The BIN system uses the RESL algorithm to reach decisions on the number of MOTU's in a sequence dataset through a three-phase analysis based on sequence variation with a $2.2 \%$ threshold of maximum divergence allowed within a cluster.

ABGD employs a multi-phase system which initially divides sequences into MOTUs based on a statistically inferred barcode gap (i.e., initial partitioning), and subsequently conducts additional rounds of splitting (i.e., recursive partitioning). It is a statistical method that explores the distribution of all pairwise distances looking for the gap between intra- and interspecific distances. An online version of ABGD (http://wwwabi.snv. jussieu.fr/public/abgd/abgdweb.htm) was employed using default parameters and $\mathrm{K} 2 \mathrm{P}$ as the distance metric.

The mPTP is a multi-rate Poisson tree processes for single-locus species delimitation under maximum likelihood and Markov chain Monte Carlo (Kapli et al., 2017). For this analysis, also an online version was used (http://mptp.h-its.org/\#/tree).

Finally, TCS applies the statistical parsimony method to construct haplotype networks. It has been shown that the count of Linnaean species present in a COI alignment greatly matches that of independent statistical parsimony networks inferred by the software. A nexus file was generated to calculate a TCS network (Clement et al., 2002) in PopART (http://popart.otago.ac.nz) (Leigh \& Bryant, 2015). This Interface permits to visualize in a graph the network of relationships between the haplotypes and geographical distributions. 

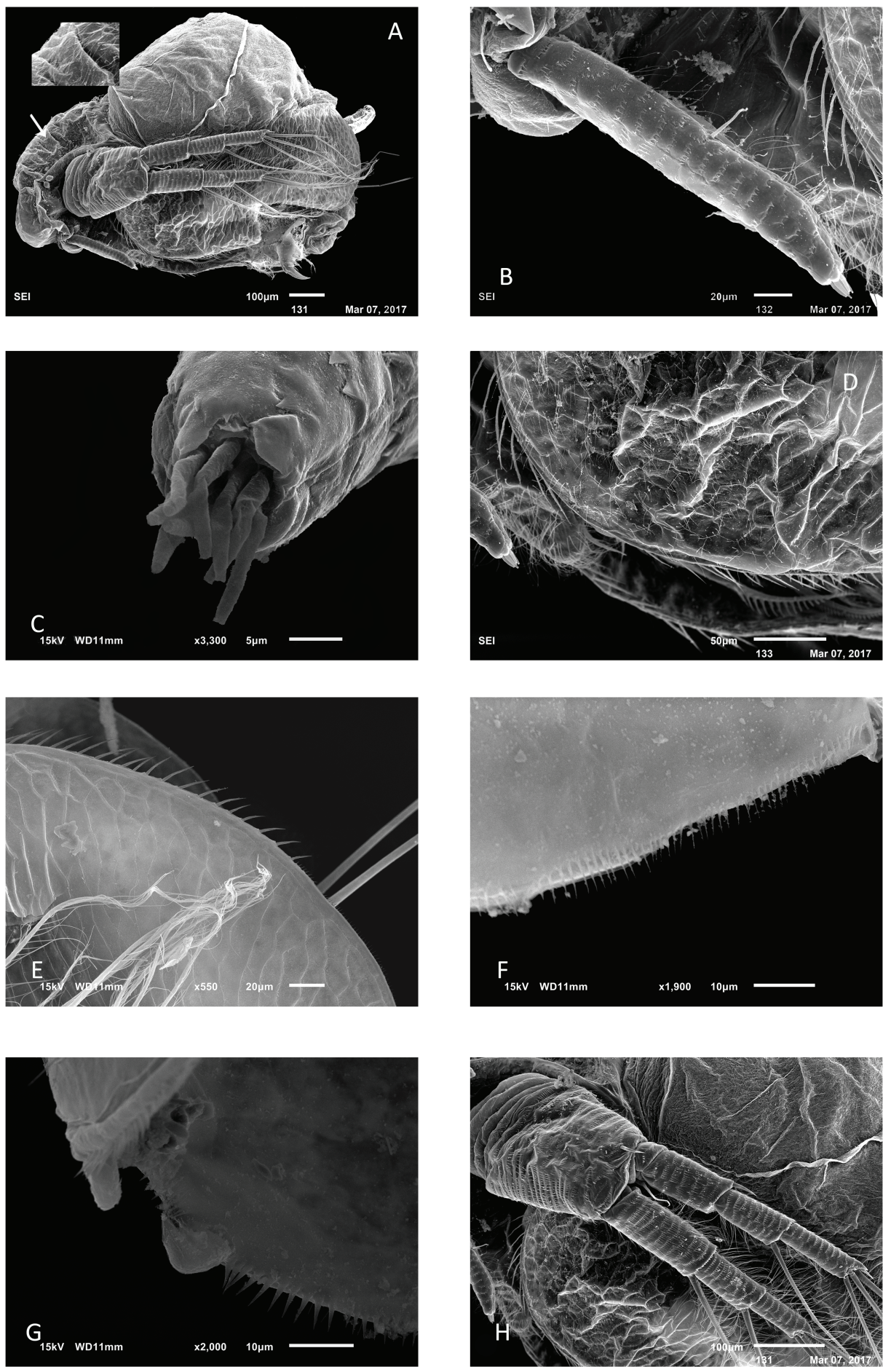

Figure 1. SEM observations of Moina macrocopa s.1. (Female). A. Habitus, arrow: magnification of hairs. B. Antennule. C. Tip of the antennule. D. Anterior shell rim and first limb. E. Posterior shell rim, exterior view. F. Posterodorsal shell rim, interior view. G. Dorsal shell rim and hooks. H. Antenna. Observaciones de Moina macrocopa s.l (hembra) con el Microscopio Electrónico de Barrido. A. Hábito. B. Anténula. C. Punta de la anténula. D. Margen anterior del caparazón y pata I. E. Margen posterior del caparazón, vista exterior. F. Margen postero-dorsal del caparazón, vista interior. G. Margen dorsal del caparazón y ganchos. H. Antena. 

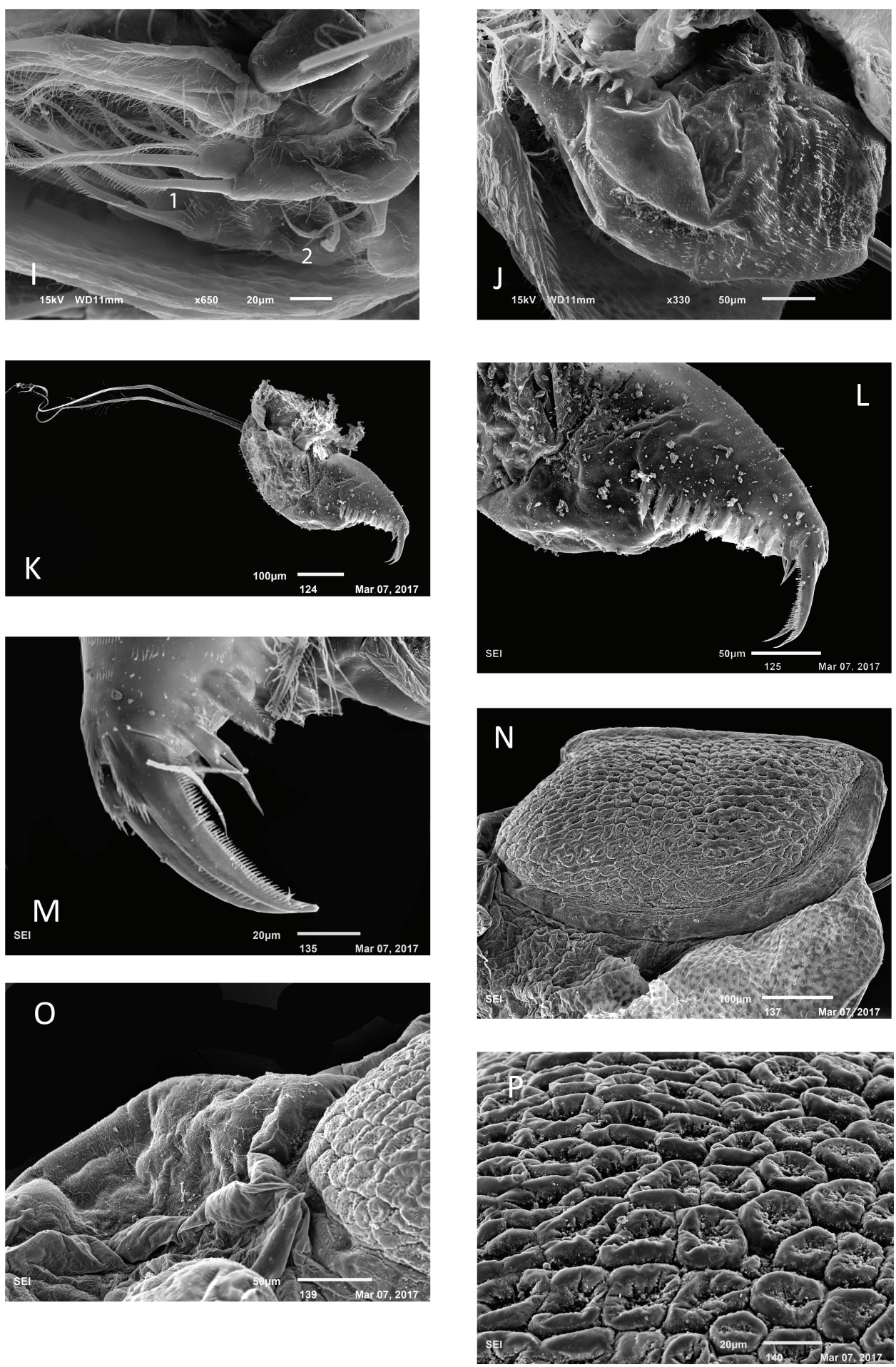

Figure 1 (cont.). Moina macrocopa s.1. I. First limb, 1: toothed seta, 2: ejector hooks. J. Postabdomen. K. Postabdomen and swimming setae. L. Claw and feathered teeth. M. Claw and pecten. N. Ephippium, lateral view. O. Head and ephippium. P. Surface of ephippium. M. macrocopa s.l. I. Pata I, 1: seta dentada, 2: ganchos eyectores. J. Postabdomen. K. Postabdomen y setas natatorias. L. Garra y dientes plumosos. M. Garra y pecten. N. Efipio, vista lateral. O. Cabeza y efipio. P. Superficie del efipio. 

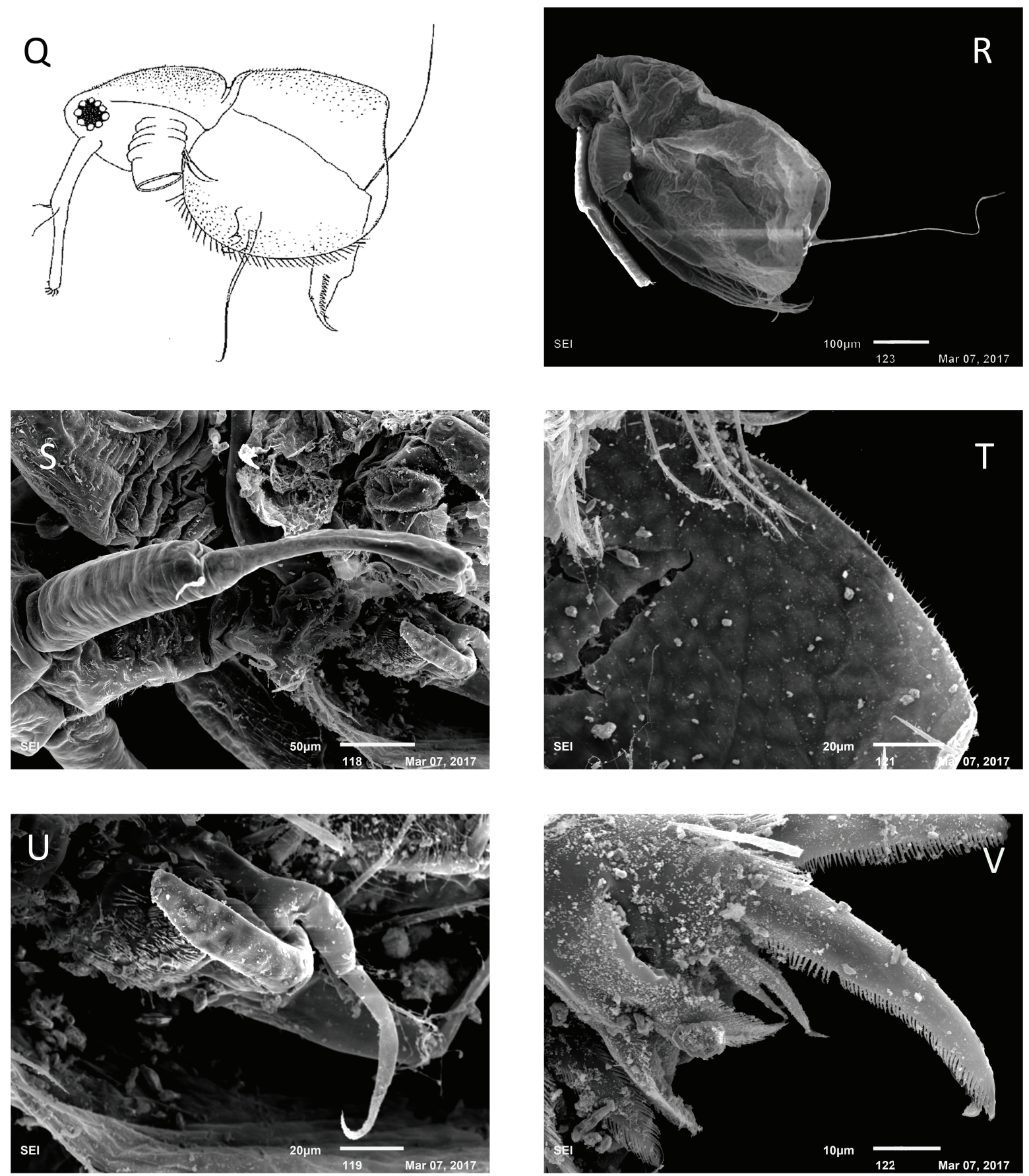

Figure 1 (cont.). Moina macrocopa s.1. (Male). Q. Habit, illustration of Alonso (1996). R. Habit. S. Antennula. T. Posterior shell rim. U. First limb, inmature form. V. Claw. All specimens for SEM are from Calderitas (Mexico). Moina macrocopa s.l. (Macho). Q. Hábito, ilustración de Alonso (1996). R. Hábito. S. Anténula. T. Margen posterior del caparazón, vista interior. U. Pata I, forma inmadura. V. Garra. Todos los especímenes para Microscopía Electrónica de Barrido (MEB) fueron recolectados en Calderitas (México). 


\section{Genetic diversity analysis}

The alignments in FASTA format were imported into DnaSP v5 to perform haplotype diversity indexes and verify results obtained by TCS network (Librado \& Rozas, 2009).

\section{RESULTS}

\section{Morphological observations}

Family Moinidae Goulden, 1968

Genus Moina Baird, 1850

Moina macrocopa (Fig. 1A-P)

Synonymy uncertain

Type locality: unknown, Europe. Considering that the majority of the species described by Straus where from France, as Daphnia magna (Straus, 1820) and the proximity of France (terra typica) and Spain, we consider that the population shared between Spain, Russia and Calderitas (Mexico) corresponds to the real Moina macroco$p a$ s. str. (Straus, 1820).

Material examined: One parthenogenetic female from Albufera de Valencia (Spain) $(32.296 \mathrm{~N}, 0.316 \mathrm{~W}) .10$ specimens from a rain pond in Calderitas (Quintana Roo state, Yucatan Peninsula, Mexico) (18.6308 N; 88.2251 W) probably recently introduced.

\section{Parthenogenetic female}

Size: Mean: body length $1.3 \pm 0.103 \mathrm{~mm}$; body wide $81 \pm 0.08 \mathrm{~mm}$; body ratio (length/wide): $0.656 \pm 0.008 \mathrm{~mm}(\mathrm{~N}=10)$. Color of specimens: brownish.

The morphological features of the Mexican specimens from Calderitas and those from Spain match with the typical form (Fig. 1). The head and shell surface are covered with scattered long hairs, the head broad with a slightly supraocular depression (Fig. 1A, arrow) and there is an oval "nucal pore" close to the dorsal end of the head, similar to Moina americana Goulden, 1968 n. stat. (Fig. $2 \mathrm{~B}, \mathrm{C})$. These characters were also examined in the Argentinean and Spanish specimens of Paggi (1997) and Alonso (1996), respectively, but were not mentioned by Goulden (1968), although it is possibly the most significant character of the species complex, since it has not been reported in other congeners as i.e. Moina micrura.

The shell is deeply reticulated (visible at SEM) with hairs appearing on the border of the polygons (Fig. 1D). The hairs are denser at the anterior part of the shell and disappear at the dorsal part. The number of setae in the ventral rim of the shell ranges from fifty-five to seventy (Fig. 1D,E), the $\neg$ posterior edge has a submarginal, continuous row of fine spinules (Fig. $1 \mathrm{E}, \mathrm{F})$, and at the dorsum there is a pair of hooks, one on each valve (Fig. 1G). The setae of the anterior rim are slightly feathered. The antennule is cylindrical (mean length: $0.214 \mathrm{~mm}$; mean ratio width/length: 0.22 ), ciliated, slightly curved on the tip and in its surface has many short rows of spinules around it (Fig. 1B). At the tip of the antennule, there are nine aesthetascs (only eight visible at Fig. 1C) with flat tip and without projections as in Moina micrura. The sensory seta is long, but not as long as described in Goulden (1968) and Paggi (1997), and it is inserted in the mid-point of the antennule (Fig. 1B). The antennae are robust, covered with many rows of spinules. Both branches have medial rows of long and fine setulae and the usual distribution of swimming setae $(1-1-3 / 0-0-1-3)$ and spines $(0-0-1 / 0-1-0-1)$. The sensory setae of the basipodite are approximately equal in length, about one-third the length of the segment. The basipodite covered by a row of spines parallel to it, and one stout spine at the tip (Fig. 1H).

The first trunk limb has the setation pattern common to most species of Moina (3-2-2-3), eight feathered setae, two toothed setae, and two ejector hooks (Fig. 1I). The anterior seta of the penultimate segment has a row of stout and distal teeth that may be longer than the seta's width. (Fig. 1I). The teeth on the seta of the last segment are much smaller but higher in number and closer than the penultimate tooth seta. The limb II presents the two setae of the proximal group of the gnathobase of the same size as described in Alonso (1996). We did not consider it as a signifi- 
cant taxonomical feature because it is similar in other congeners and does not present any variation in the studied populations. In Limb IV Alonso (1996) cited that the setae of the filter plate are relatively separated than the other congeners, but we did not find any significant difference with other congeners i.e. populations of Moina micrura complex (pers. obs.).

The postabdomen is long and robust with many short rows of spinules at the dorsal and lateral sides (Fig. 1J) with two biarticulated natatory setae with long hairs at the distal part (Fig. 1K). The conical distal part of the postabdomen carries 7-10 feathered teeth, as Goulden (1968) described instead of 9-11 teeth cited by Paggi (1997), and one bifid tooth (Fig. 1L). The branches of the bifid tooth are distinctly unequal. There are some scattered tiny spinules near the base of the bifid tooth. The inner side of the claw has a continuous row of fine setae a little thicker than those on the outer side. On the ventral base, there is a pecten with seven teeth (Fig. 1M) only visible at SEM.

The surface of the ephippium is covered with thick rounded cells and contains two eggs (Fig. $1 \mathrm{~N}-\mathrm{P}$ ). It is sub rectangular in lateral view (Fig. $1 \mathrm{~N})$.
Male (Fig. 1Q-U)

Size: main body length $0.52 \mathrm{~mm}(\mathrm{~N}=5)$. Color of specimens: brownish.

The body male and head are covered with hairs (Fig.1Q,R), longer and denser on the body. The head lacks the supraocular depression. The long antennules originate below the eye, are bent at the mid-point and have two sensory setae arising at or near the knee of this bend (Fig. 1S). The distal halves of the antennules are curved inward and have four to six short hooks at the tip. The hooks form a semicircle around a group of sensory papillae that project from the end of the antennule. The surface of the shell is reticulated and covered with hairs, as mentioned above. The ventral rim has 35-40 marginal setae. The shorter spines along the posterior margin of the shell are ungrouped and scattered as in the female (Fig. 1T).

The first limb of the male has a long, recurved hook originating from the penultimate segment (Fig. 1U). The terminal segment carries three setae; the middle seta is long and hook-like. The other two setae are feathered. The penultimate segment covered with many short hairs along the medial margin, and there is a seta arising from this surface opposite the hook. The first limb has

Table 1. Morphological differences between species and sexes. Diferencias morfológicas entre especies y sexos.

\begin{tabular}{lll}
\hline Characters & Moina macrocopa (Straus, 1820) & Moina americana Goulden, 1968 n. stat. \\
\hline Female & & \\
\hline Antennulae (A1) & Sensory seta inserted in the middle & Sensory seta longer, inserted in the first third \\
\hline $\begin{array}{l}\text { Setae of posterior } \\
\text { shell rim }\end{array}$ & No groupings & Forming three groups \\
\hline $\begin{array}{l}\text { Setae of dorsal shell } \\
\text { rim }\end{array}$ & Fine spinules & Stout and robust spinules \\
\hline Toothed seta of LI & Fine and separate teeth & A row of stout teeth, smaller and more numerous \\
\hline Ephippium & Round cells & Trapezoidal cells \\
\hline Male & & \\
\hline Limb I & Large recurved hook & Very large recurved hook \\
\hline Genital openings & Ventral to the claw & At the end of the feathered teeth \\
\hline
\end{tabular}


an exopod segment that terminates with a very long seta which is longer than the limb and reaches to the posterior margin of the shell. This seta is usually bent ventrally and projects well beyond the ventral margin as in the review of Goulden (1968). The postabdomen and the claw of the male are similar to the female. However, the conical part of the postabdomen is much broader, and the claw projects from the middle of the distal margin of the postabdomen (Fig. 1V).

Habitat: In Spain, this species has only appeared in the Albufera of Valencia, and related water bodies (Arévalo, 1920; Alonso, 1996) such as the rice fields at the south part of the lake. In these rice fields, the quality and stationarity of the water mass depend on the rice cultivation cycle. During the summer waters are transparent, but loaded with organic matter from rice fertilizers, shallow (about $25 \mathrm{~cm}$ depth) and come from Jucar River, so they are always renewing. In Calderitas (Mexico), we collected a possibly recently introduced specimens, from a temporary pond formed by the rain, with a high organic load.

Moina americana Goulden, 1968 n. stat. (= Moina macrocopa americana (Goulden, 1968))

Type locality: According to Goulden (1968), a roadside ditch, along a county road one mile east of the Cheyenne Bottoms Waterfowl Refuge in Barton County, Kansas (USA). Sequenced specimens from near terra typica were collected in a pond in Denver (40.73 N, -104.40 W).

Type specimens of this subspecies are in the Smithsonian Institution National Museum of Natural History (Catalogue Numbers Holotype 123203; Paratypes 123204).

Material examined: 15 specimens from Texcoco Lake (State of Mexico, Mexico) (19.45 $\mathrm{N},-99.00 \mathrm{~W}$ ) and 10 specimens from Los Gringos dam (Aguascalientes, Mexico) (21.91 N, $-102.26 \mathrm{~W})$.

\section{Diagnosis (see Table 1)}

Moina americana n. stat. can be easily distinguished from Moina macrocopa s.l. for the following characters: the sensory seta of the antennule is longer, and it is inserted in the first third (Fig. 2D); the spines on the posterior rim of the valves form groups increasing in size (Fig.
2I). Following these spines at the dorsal part, there is a row of stout and robust spinules instead of fine spinules as is present in Moina macocopa; the first trunk limb presents the anterior seta of the penultimate segment with a row of stout teeth, finer and more numerous than in $M$. macrocopa s.1. (Fig. 2J). The ephippium is bigger than $M$. macrocopa, its surface covered with trapezoidal cells instead of round with the point slightly curved upwards (Fig. 2M-N). The male's first limb has a very large recurved hook, originating from the penultimate segment more prominent than in the Old World form and presents several tiny spinules on the tip (Fig. 3F).

\section{Parthenogenetic female (Fig. 2A-L)}

Size: Length $1.14 \pm 0.05 \mathrm{~mm}$; width $0.83 \pm 0.05$ $\mathrm{mm}$ and ratio: $0.729 \pm 0.005(\mathrm{~N}=10)$. Color of specimens: whitish. In life sometimes red, due to the presence of hemoglobin.

The revised material agrees with the typical form described by Goulden (1968): the setae along the posterior shell rim grouped, some being much larger than the others and there are usually two or three groups with large teeth located just posterior to the ventral row of setae. Long and dense hairs cover the body and head, more than the European clade (Fig. 2A,B). The head presents a broad and slightly supraocular depression and an oval "nucal pore", cited by Alonso (1996) and Paggi (1997) in the Old World form but never cited before for the American form (Fig. 2B,C). Labrum hairy, covered with many scattered fine and long hairs, the proximal part very bulky (Fig. 2F). The shells are sub rectangular and rounded in lateral view (Fig. 2G), with a row of stiff feathered marginal setae (Fig. 2H). The spines of the posterior rims are grouped and ordered in increasing in size (Fig. 2I) followed by a continuous row of fine spinules. The antennule is cylindrical, shorter than in M. macrocopa s.1. (mean length: $0.25 \mathrm{~mm}$; mean ratio width/length: $0.188 \mathrm{~mm}$ ), ciliated, slightly curved on the tip and in its surface presents long rows of spinules around it (Fig. 2D,E). The sensory seta is also longer than the European specimens analyzed and is inserted in the first third of the antennule (Fig. 2D). The antennae are robust, covered with many rows of 

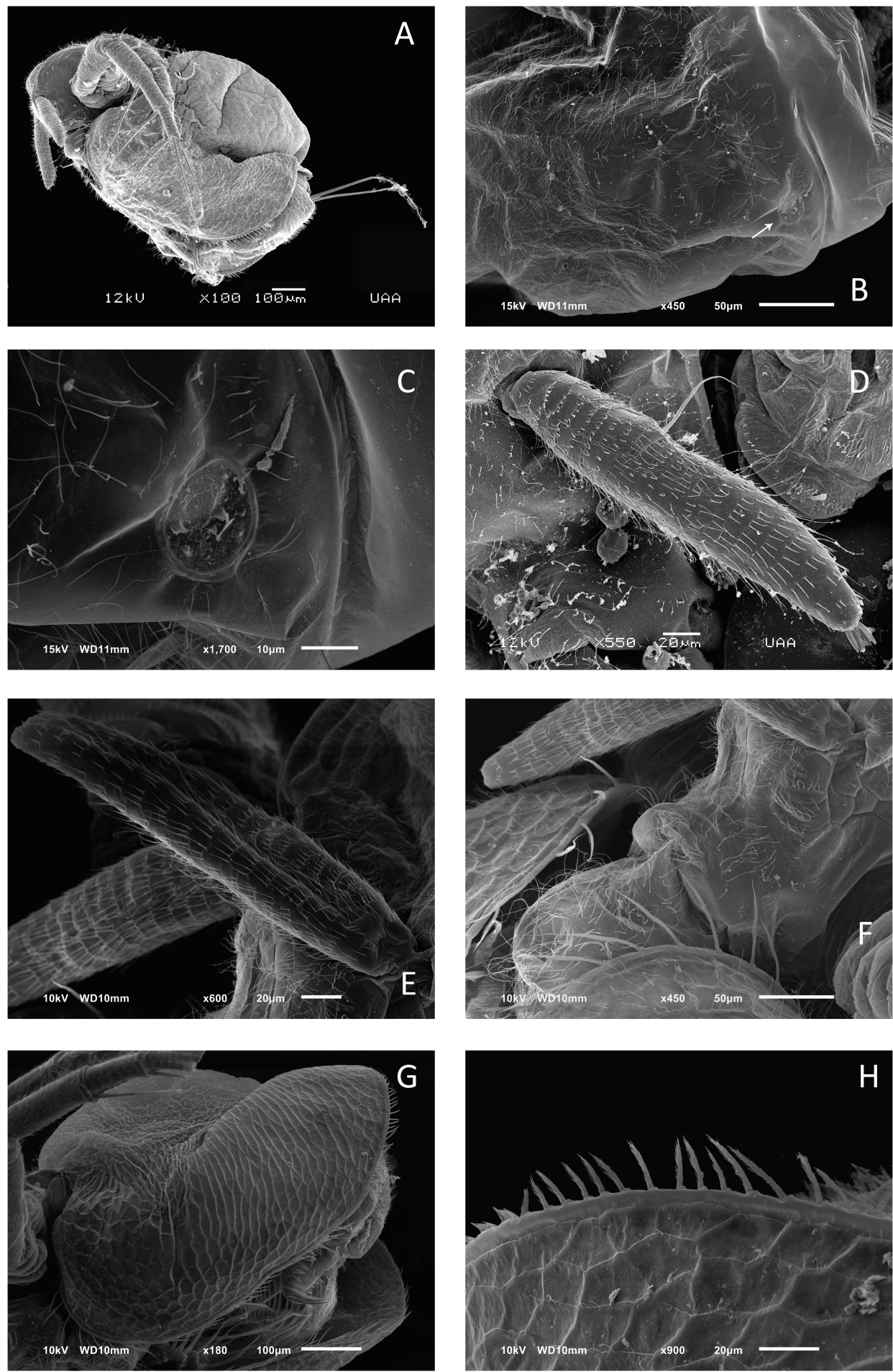

Figure 2. SEM observations of Moina americana Goulden, 1968 n. stat. (Female). A. Habit. B. Nucal pore on head. C. Magnification of the nucal pore. D, E. Antennula. F. Labrum. G. Shell, lateral view. H. Anterior shell rim. Observaciones de Moina americana Goulden, 1968 n. stat. (Hembra) con el Microscopio Electrónico de Barrido. A. Hábito. B. Órgano nucal. C. Magnificación del órgano nucal. D,E. Anténula. F. Labro. G. Caparazón vista lateral. H. Margen anterior del caparazón. 

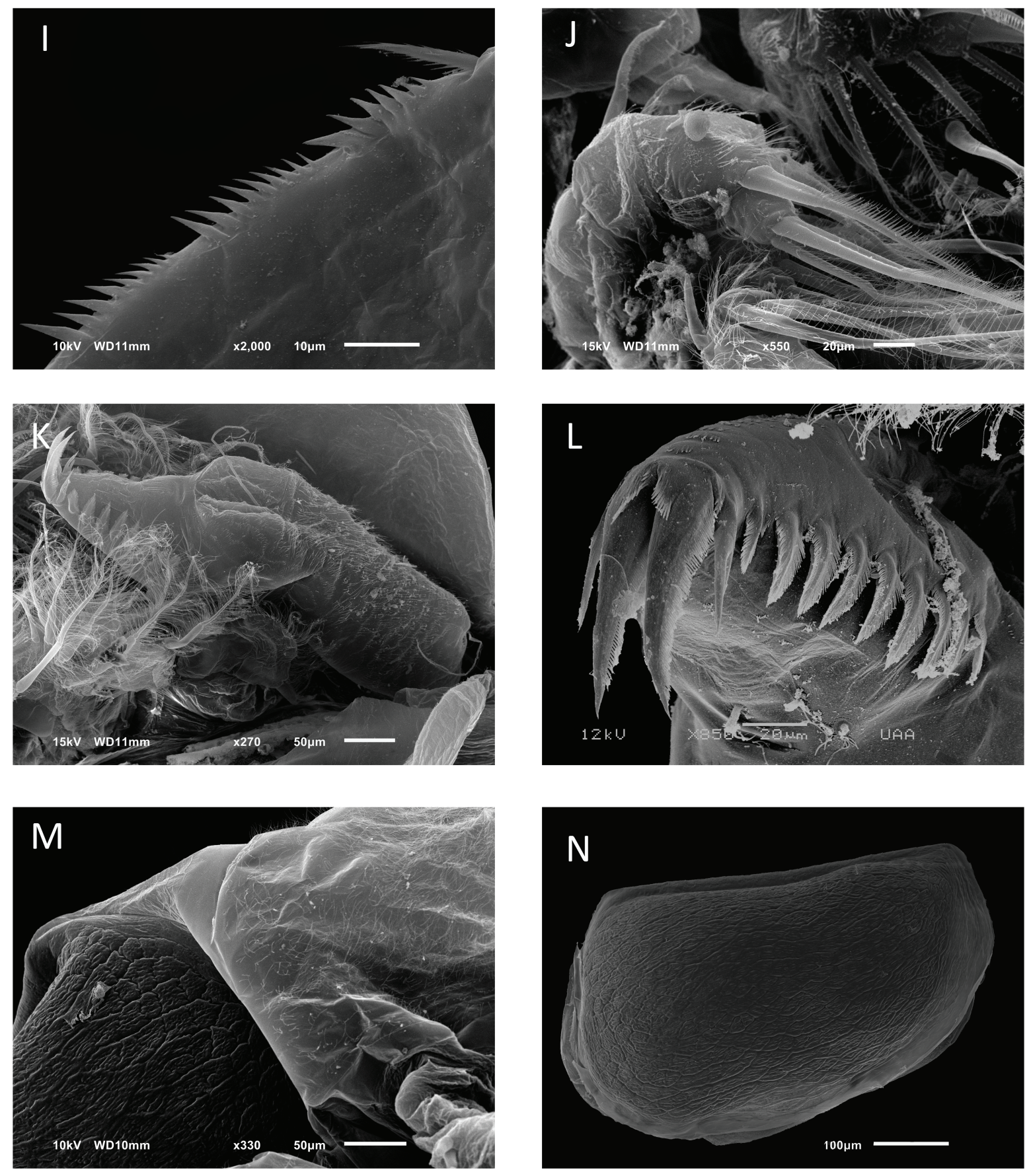

Figure 2 (cont.). Moina americana n. stat. I. Groups of setae present at the posterior shell rim. J. First limb. K. Postabdomen. L. Claw and feathered teeth. M. Head and ephippium. N. Ephippium, lateral view. Specimens for SEM are from Texcoco lake (City of Mexico) and Los Gringos dam (Aguascalientes, Mexico). Moina americana $n$. stat. I. Grupos de setas presentes en el margen posterior del caparazón. J. Pata I. K. Postabdomen. L. Garra y dientes plumosos. M. Cabeza y efipio. N. Efipio, vista lateral. Especimenes para MEB recolectados en el Lago Texcoco (Ciudad de Mexico) y en la presa de Los Gringos (Aguascalientes, México). 
spinules. Both rami with medial rows of long and fine setulae and the usual distribution of swimming setae (1-1-3/0-0-1-3) and spines (0-0-1/0-1-0-1) (Fig.2A, H). The sensory setae of the basipodite are approximately equal in length, about half the length of the segment. The basipodite covered by a row of spines parallel to the segment, and one stout spine at the tip. (Fig. 2A).

The first trunk limb presents eight feathered setae, two toothed setae, and two ejector hooks of different size. The anterior seta of the penultimate segment has a row of stout teeth, smaller and more numerous than in M. macrocopa s.l. (Fig. $2 \mathrm{~J})$. The postabdomen is similar to the Old World specimens but hairier (Fig. 2K) It is very long and robust with many short rows of spinules at the dorsal and lateral sides. The conical distal part carries nine feathered teeth and one bifid tooth (Fig. 2L). The branches of the bifid tooth are distinctly unequal. There are small groups of spinules near the base of the bifid tooth. The inner side of the claw has a continuous row of fine setae a little thicker than those on the outer side. On the ventral base, there are thirteen teeth (Fig. L).

The surface of the ephippium composed of flat cells that are more trapezoidal then square in cross section and contains two eggs. It is bigger than in Moina macrocopa s.l. and seems like a water drop with the point slightly curved upwards (Fig. 2M,N).

\section{Male (Fig. 3A-L)}

The body male and head are hairy, lenght 0.92 $\mathrm{mm}(\mathrm{N}=10)$. The shell is deeply reticulated, the setules grow mainly in the contours of these polygons. The head lacks the supraocular depression (Fig. 3A,M) but also presents reticulation on dorsal view. The long antennules originate below the eye, they are bent at the mid-point and have two sensory setae arising at or near the knee of this bend (Fig. 3D). The distal halves of the antennules are curved inward with a row of tiny spinules on the tip and four to six short brush-like setae (Fig. 3E). The brush-like setae form a semicircle around a group of sensory papillae that project from the end of the antennule (Fig.3D). The antennae are robust, covered with many rows of spinules. Both rami with middle rows of long and fine setulae and the general distribution of swimming setae is $1-1-3 / 0-0-1-3$ and spines $0-0-1 / 0-1-0-1$. The sensory setae of the basipodite are approximately equal in length, about one-third the length of the segment. The basipodite covered by a row of spines parallel to the segment, and one stout spine at the tip. (Fig. 3G). The surface of the shell is reticulated and covered with hairs, as mentioned above (Fig.3A). The ventral rim has 34-43 marginal setae. The setae along the posterior margin of the shell are grouped and ordered in increasing size (see 1 in Fig. $3 \mathrm{H}$ ) followed by a continuous row of fine spinules (Fig.3I). At the dorsal rim, there are some stiff spinules, stronger than in the European form, followed by two hooks (Fig. 3J).

The first limb of the male has a large recurved hook, originating from the penultimate segment, bigger than Old World specimens (Fig $3 F)$. The terminal segment carries three setae; the middle seta is very long and hooklike without spinules on the tip (see a in Fig. 3F) as in other congeners as Moina micrura. The other two setae are feathered. The penultimate segment covered with many grouped short hairs along the medial margin, and there is a seta arising from this surface opposite the hook. The first limb has an exopod segment that terminates with a very long seta which is longer than the limb and reaches to the posterior margin of the shell and presents several little teeth on the tip (see b in Fig. 3F). These latter are absent in $M$. macrocopa s.l.

The postabdomen and the claw of the male, are similar to the female. However, the conical part of the postabdomen is much broader, and the claw projects from the middle of the distal margin of the postabdomen (Fig. 3K). The two genital openings are just at the end of the feathered teeth row, in lateral view, one on either side of the postabdomen not as in Moina macrocopa s.l. where they are ventral to the claws (see arrow and magnification in Fig. 3L).

Habitat: Los Gringos dam is in central highlands of Mexico, in the city of Aguascalientes $(21.91 \mathrm{~N} ; 102.268 \mathrm{~W})$. The waters of this dam are highly eutrophicated due to the fact that it received the sewage water from the nearby neighborhood. Texcoco Lake is in the east of Mexico 

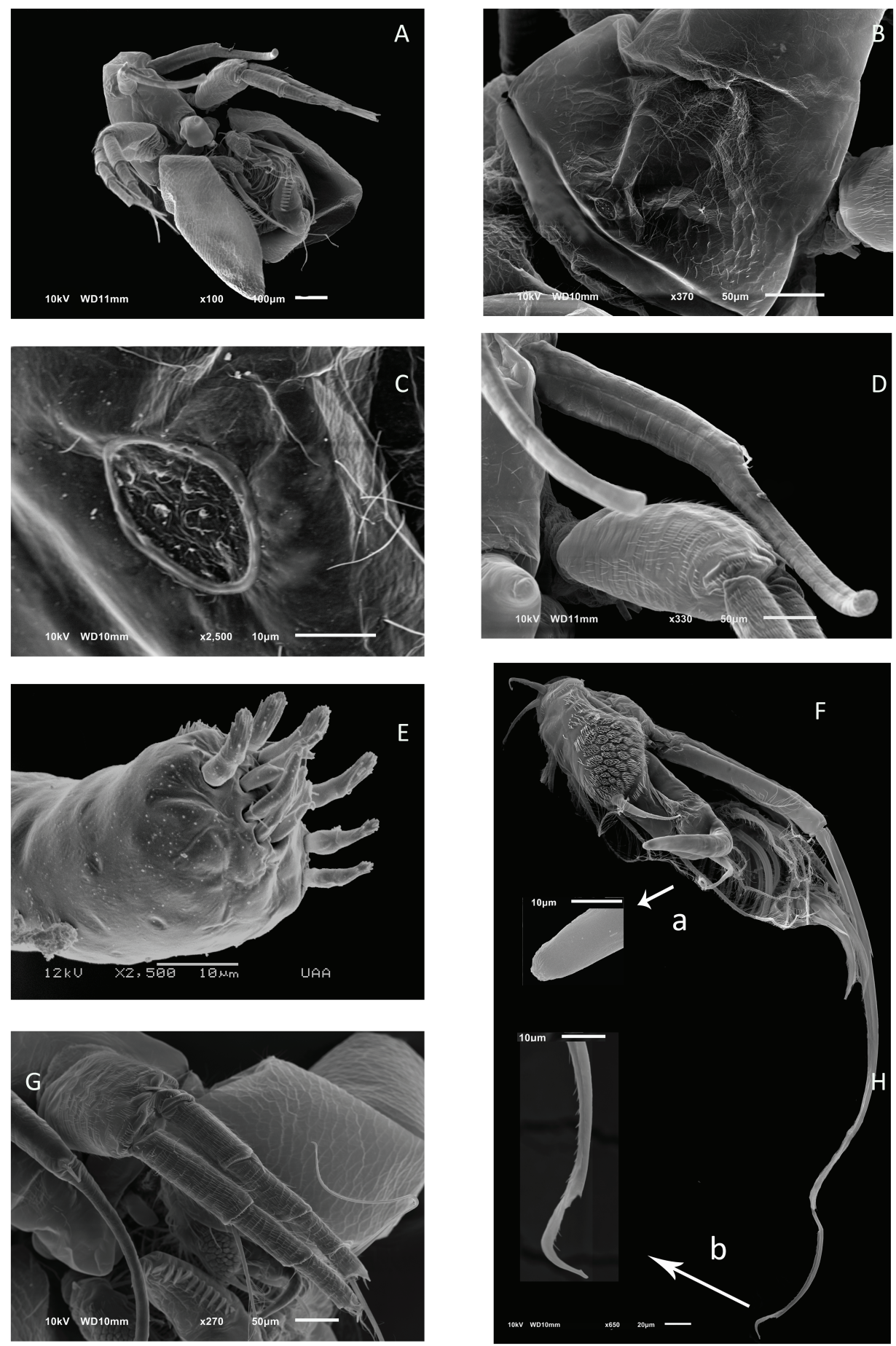

Figure 3. SEM observations of Moina americana Goulden, 1968 n. stat. (Male). A. Habit. B. Nucal pore on head. C. Magnification of the nucal pore. D. Antennules. E. Tip of the antenne, brush-like setae and aesthetascs. F. First limb, a: tip of the hook, b: tip of the middle seta of the penultimate segment. G. Antenne. Observaciones de Moina americana Goulden, 1968 n. stat. (macho) con el Microscopio Electrónico de Barrido. A Hábito. B. Órgano nucal. C. Magnificación del órgano nucal. D. Anténulas. E, Punta de la antena, setas tipo brocha y estetascos. F. Pata I, a: detalle del gancho, b: punta de la seta del medio del penúltimo segmento. G. Antena. 

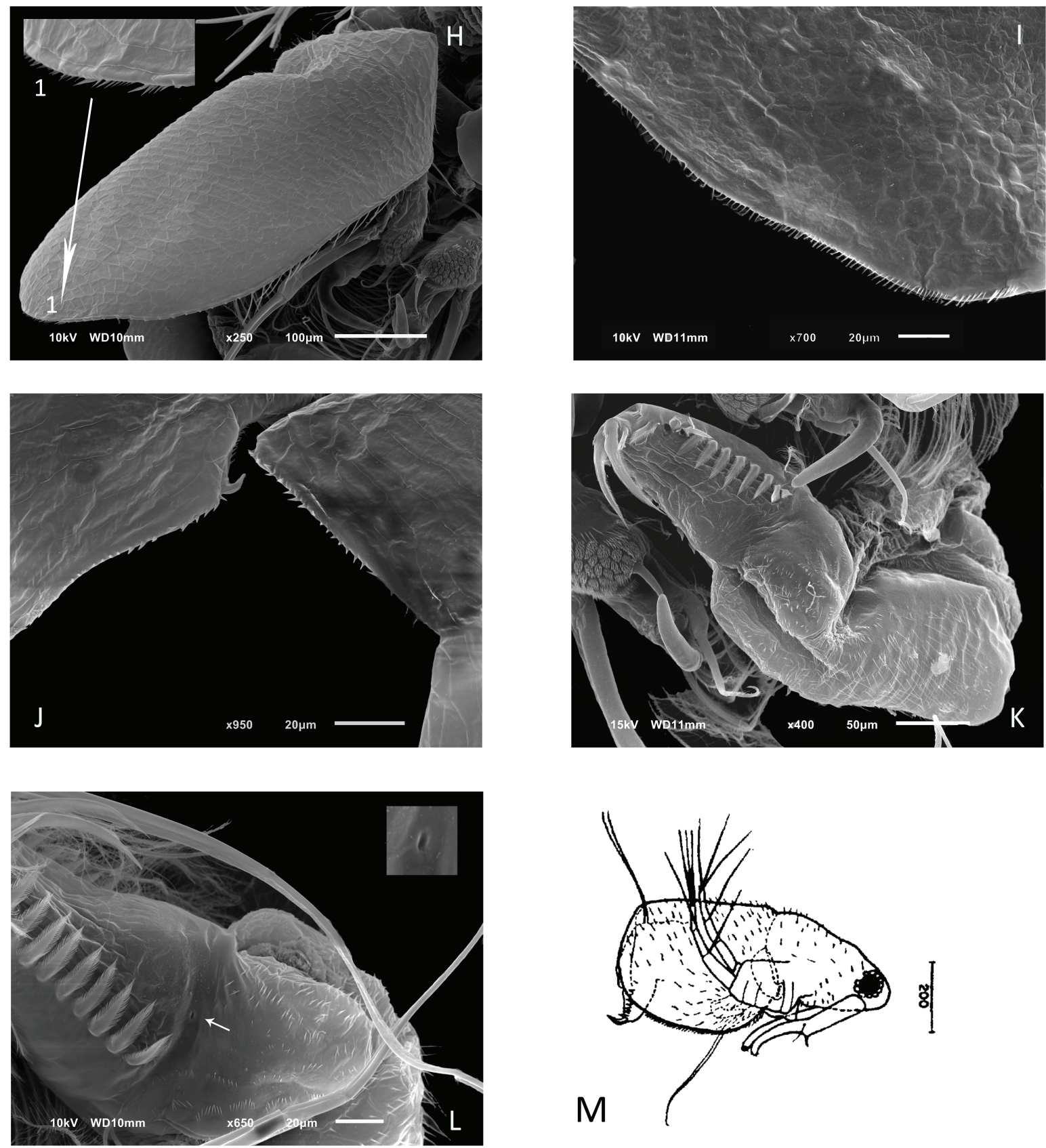

Figure 3 (cont.). M. americana n. stat. Male. H. Shell lateral view. I. Posterior shell rim, interior view. J. Dorsal shell rim and hooks. K. Postabdomen, claw and feathered teeth. L. Gonopores, arrow: shows the estructure. M. Drawing from Goulden (1968). Specimens for SEM from Texcoco Lake (City of Mexico). M. americana n. stat. Macho. H. Caparazón, vista lateral. I. Margen posterior del caparazón, Vista interior. J. Margen dorsal del caparazón y ganchos. K. Postabdomen, garra y dientes plumosos. L. Gonoporos, flecha: muestra la estructura. M. Dibujo de Goulden (1968). Especímenes para MEB recolectados en el Lago Texcoco (Ciudad de Mexico). 
City (19.452 N; $98.995 \mathrm{~W})$, located at 2.236 meters above the sea level in the TransMexican volcanic belt (Alcocer \& Bernal-Brooks, 2010). This saline soda-lake is highly polluted and eutrophicated and supports an active anthropogenic pressure since the arrival of the Aztecs in the XIV century (Alcocer \& Bernal-Brooks, 2010).

\section{Remarks}

We have found morphological differences between the two populations of the European clade inhabiting in Calderitas, such as the spinulation pattern of the posterior shell rim and the antennule, which have direct correspondence with genetical results commented later. But to describe this possible new species, further genetical and morphological comparative studies must be done.

\section{Genetic analyses}

We created a dataset of 55 sequences under the name of DS-MMACRO in BOLD Systems database. It includes 57 sequences of Moina macrocopa complex and one sequence of Moina cf. micrura 2, (Elías-Gutiérrez et al., 2008a), used as an outgroup. The "barcode identification request" in BOLD showed five different BINs. Sequences matching European clade (possibly including the real Moina macrocopa (Straus, 1820), assigned to three different BINs, BIN: BOLD:ACH4664 (sampled from Hungary, Russia and Mexico, Calderitas), BIN: BOLD:ACA1705 (Spain, Russia and Mexico, Calderitas) and BIN: BOLD:AAK6825 (European Russia). Sequences matching the American clade, including specimens near the original type locality,

\begin{tabular}{|c|c|c|c|c|c|c|c|c|c|c|c|c|c|c|}
\hline \multirow[b]{3}{*}{ Marker } & \multirow{3}{*}{$\begin{array}{c}\text { BIN } \\
\text { System }\end{array}$} & \multirow{3}{*}{$\begin{array}{l}\text { mPTP } \\
\text { Model }\end{array}$} & \multicolumn{12}{|c|}{ ABGD } \\
\hline & & & \multicolumn{2}{|c|}{0.0017} & \multicolumn{2}{|c|}{0.0028} & \multicolumn{2}{|c|}{0.0077} & \multicolumn{2}{|c|}{0.0129} & \multicolumn{2}{|c|}{0.0215} & \multicolumn{2}{|c|}{0.0359} \\
\hline & & & 1 & $\mathrm{R}$ & 1 & $\mathrm{R}$ & 1 & $\mathrm{R}$ & 1 & $\mathrm{R}$ & 1 & $R$ & 1 & $\mathrm{R}$ \\
\hline $\mathrm{COI}$ & 5 & 3 & 3 & 3 & 3 & 3 & 3 & 3 & 2 & 3 & 2 & 3 & 2 & 3 \\
\hline
\end{tabular}

Table 2. OTUs of Moina macrocopa complex by three different species delimitation methods. UTOs del complejo Moina macrocopa aplicando tres métodos diferentes para delimitar las especies.
Moina americana Goulden, 1968 n. stat. were assigned to a unique BIN: BOLD:AAC3108 and finally, sequences assigned to BIN: BOLD:ADF9261 correspond to the Asiatic clade found in Russia, shown by Bekker et al. (2016).

MPTP and ABGD analyses gave three groups instead of five as Barcode Identification request showed (Table 2). These three groups correspond to European clade (possibly the real Moina macrocopa (Straus, 1820), American clade Moina americana Goulden, 1968 n. stat. and the Asiatic clade (Moina cf. macrocopa). Differences in the number of groups delimited by BIN system and the other tools (MPTP and ABGD) five and three respectively, is due to the BIN system that is more sensitive than the other tools. It uses a threshold of maximum divergence of $2.2 \%$ to delimitate the clusters and it should be mentioned that is continuously evolving in new BINs if more information is added (Ratnasingham \& Hebert, 2007, 2013).

Kimura 2-parameters (K2P) mean intraspecific distances for each population in Moina macrocopa s.1. (European clade) are: $0.41 \%$ in BOLD:ACH4664, $0 \%$ in BOLD:AAK6825 and $0.75 \%$ in BOLD:ACA 1705 . In the case of Moina americana Goulden, 1968 n. stat. (American Clade, BIN number BOLD:AAC3108), the mean intraspecific distance is $0.64 \%$. (Table 3). Interspecific distances ranged from $3.72 \%$ to $13.36 \%$. The European clade showed the minimum mean interspecific distance between its populations (Russian population has not been considering for this analysis, due to the low number of available sequences in BOLD). The biggest mean interspecific distance $13.36 \%$ is between the Asiatic clade (BOLD:ADF9261) evidenced by Bekker et al. (2016) and the European population with BIN number BOLD:ACA1705 that it is distributed in Hungary, Mexico and Russia.

The low intraspecific divergence showed by the American clade (BOLD:AAC3108) which includes sequences from terra typica in North America and other places from North and South America suggest the incipient expansion of this species. The high divergence in the European clade indicates that Moina macrocopa s.1. is possibly a species complex composed by at least three distinct species, two of them confirmed by 
Table 3. K2P Mean Genetic divergences (intra and interspecific) of Moina macrocopa complex. Bold capitals: Mean Intraspecific distances. Abbreviations: H: Hungary, MX: Mexico, RS: Russia, SP: Spain, and CA: Canada. Divergencias genéticas K2P medias (intra e interespecificas) del complejo Moina macrocopa. Letra en negrita: Distancias intraespecificas medias. Abreviaturas: H: Hungría, MX: México, RS: Rusia, SP: España y CA: Canadá.

\begin{tabular}{|c|c|c|c|c|c|}
\hline & & \multicolumn{2}{|c|}{$\begin{array}{c}\text { Moina macrocopa } \\
\text { European Clade }\end{array}$} & \multirow{2}{*}{$\begin{array}{c}\begin{array}{c}\text { Moina cf macrocopa } \\
\text { Asiatic Clade }\end{array} \\
\text { RS } \\
\text { BOLD:ADF9261 }\end{array}$} & \multirow{2}{*}{$\begin{array}{c}\begin{array}{c}\text { Moina americana } \mathrm{n} \text {. stat. } \\
\text { American Clade }\end{array} \\
\text { CA, MX } \\
\text { BOLD:AAC3108 }\end{array}$} \\
\hline & & $\begin{array}{c}\text { H, MX, RS } \\
\text { BOLD:ACH4664 }\end{array}$ & $\begin{array}{c}\text { SP, MX, RS } \\
\text { BOLD:ACA1705 }\end{array}$ & & \\
\hline \multirow{2}{*}{$\begin{array}{c}\text { Moina macrocopa } \\
\text { European Clade }\end{array}$} & $\begin{array}{c}\text { H, MX, RS } \\
\text { BOLD:ACH4664 }\end{array}$ & 0.41 & & & \\
\hline & $\begin{array}{c}\text { SP, MX, RS } \\
\text { BOLD:ACA1705 }\end{array}$ & 3.72 & 0.75 & & \\
\hline $\begin{array}{l}\text { Moina of macrocopa } \\
\text { Asiatic Clade }\end{array}$ & $\begin{array}{c}\text { RS } \\
\text { BOLD:ADF9261 }\end{array}$ & 13.36 & 12.64 & 0 & \\
\hline $\begin{array}{l}\text { Moina americana } \mathrm{n} \text {. stat. } \\
\text { American Clade }\end{array}$ & $\begin{array}{c}\text { CA, MX } \\
\text { BOLD:AAC3108 }\end{array}$ & 12.74 & 13.17 & 6.62 & 0.64 \\
\hline
\end{tabular}

Table 4. Mean GC\% content at the sequence composition of the COI Gene. Contenido medio de GC\% en la composición de las secuencias del gen COI.

\begin{tabular}{|c|c|c|c|c|c|}
\hline \multirow[b]{2}{*}{$\mathrm{BIN}$} & \multicolumn{3}{|c|}{ European clade $(36.3 \pm 0.0826)$} & \multirow{2}{*}{$\begin{array}{c}\text { Asiatic clade } \\
\text { ADF9261 }\end{array}$} & \multirow{2}{*}{$\frac{\text { American Clade }}{\text { AAC3108 }}$} \\
\hline & $\mathrm{ACH} 4664$ & AAK6825 & ACA1705 & & \\
\hline $\begin{array}{c}\text { Mean GC\% content } \\
( \pm \mathrm{SE})\end{array}$ & $36.03 \pm 0.0831$ & $35.31 \pm 0$ & $36.59 \pm 0.0496$ & $34.97 \pm 0.033$ & $35.81 \pm 0.092$ \\
\hline
\end{tabular}

morphology, genetics and distribution that corresponds to BIN numbers ACH4664 and ACA1705, the last one corresponding to the real Moina macrocopa (Straus, 1820). Finally, the high divergences between the clades from Europe and America corroborates our hypothesis that they are different species.

Regarding the GC content at the sequence composition (Table 4), it ranges from 34.97 to 36.59. Populations from cooler regions show low $\mathrm{GC}$ content than the other clades.

\section{Neighbor-Joining and Maximum Likelihood analysis}

ML analysis of COI gene is consistent with previous studies, showing that each clade is a monophyletic cluster. The branch of each cluster is highly robust (Fig. 4). We emphasize that the Id tree is not a complete phylogenetical analysis. Although it delimitates five groups, but we cannot ascertain in deep the relationships between these groups.

\section{Genetic Diversity and haplotype analyses}

Genetic diversity indexes and the results of neutrality test for COI are shown in Table 5. The average number of pairwise nucleotide differences (K), nucleotide diversity (p) and haplotype diversity (Hd) varies among the clades showing elevated levels of diversity inside the clades. A negative Tajima's D showed by the Asiatic clade demonstrates low levels of both low and high-frequency polymorphism. In total, 18 COI haplotypes were detected including four in the American clade (from two countries) (Fig. 5). The Asiatic clade included two haplotypes from 


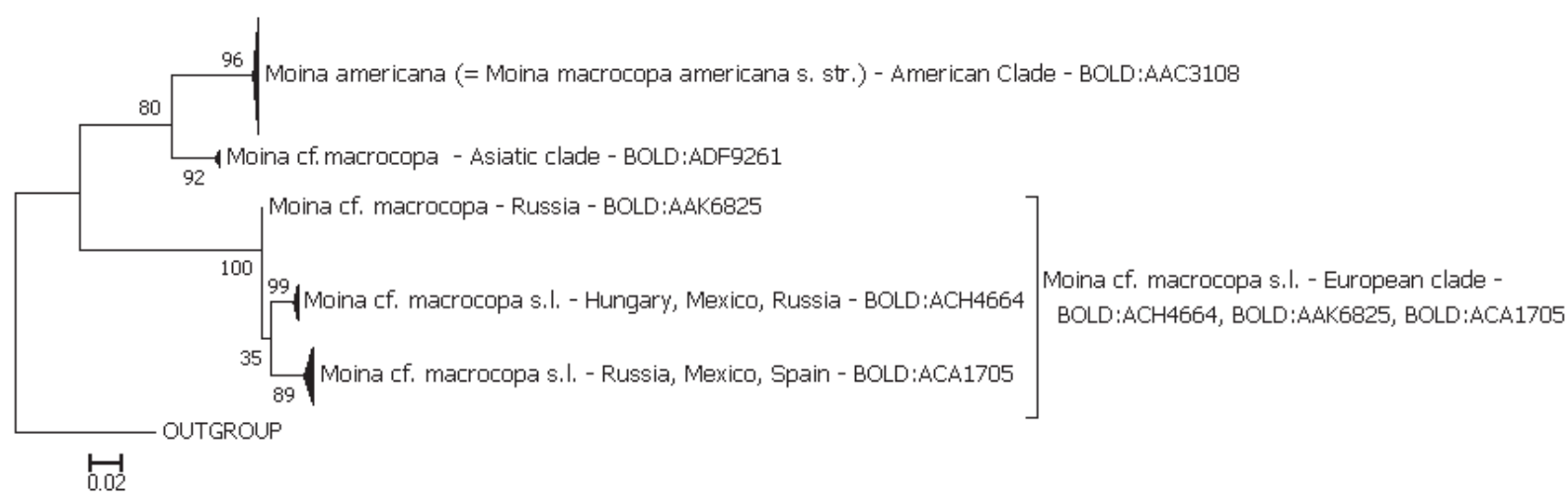

Figure 4. Id tree inferred by ML cluster analysis. Bootstrap values (500 replicates) are shown above the branches. The scale bar shows $\mathrm{K} 2 \mathrm{P}$ distances. The node of each clade with multiples specimens is collapsed to a vertical triangle, with the horizontal depth indicating the level of intraclade divergence. Árbol de identificación inferido a través del análisis de clusters de ML. Los valores de Bootstrap (500 réplicas) están sobre las ramas. La escala muestra las distancias K2P. El nodo de cada uno de los clados, está colapsado en un triángulo vertical, la profundidad horizontal indica el nivel divergencia dentro del clado.

Sakhalin area (Russia), and the European clade contained eight haplotypes from four different regions, with the dominant haplotype, shared by Hungary and Mexico (Calderitas) and the American clade also shows eight haplotypes disseminated from Canada to Bolivia.

\section{DISCUSSION}

Due to the high number of characters, analyzed in this paper, (morphological, genetical divergences and geographical distribution), and the differences found between Moina macrocopa s.l. (Old World clade) and Moina americana Goulden, 1968 n. stat. (the American clade) and with the idea to clarify this group of species, we propose to elevate to species level the subspecies Moina macrocopa americana Goulden, 1868. So, we propose the name Moina americana Goulden, 1968 n. stat., with a BIN number BOLD:AAC3108 to facilitate its identification, in place of Moina macrocopa americana Goulden, 1968.

The detailed morphological studies such the Scanning microscope allowed verification of some dubious characters, as the "nucal pore" and the claw pecten, not clearly visible using traditional techniques. The "nucal pore" according to Alonso (1996) is one of the most significant characters of the species not seen previously in other congeners, and it did not appear in the descrip- tions of the species of Goulden (1968) and Elmoor-Loureiro et al. (2010). One other variable character of the species, the faint claw pecten, has also contributed to the confusion. Depending on the view of this setation on the claw, one might either conclude that a pecten is, or is not, present. This accounts for the different description of Moina banffyi (Daday, 1883) which was said to lack a pecten while Moina esau was described as having one (Brehm, 1936). Both forms are definitely the same species. In this study we confirm the presence of these characters in the Moina macrocopa complex species and we remark the importance of the "nucal pore" to identify the species along with the anterior seta on the penultimate segment of the female's first trunk limb toothed. Differences found by Elmoor-Loureiro et al. (2010) between South American populations of Moina macrocopa s.1. must be confirmed by genetical analysis to describe the real identity of this Moina sp. In case of genetic characters, our results coincident with the morphology and the maximum divergence threshold of $3 \%$ to delimitate the species level (Hebert et al., 2003b; Bekker et al., 2016). These results also agree with the morphological differences previously published (Straus, 1820; Arévalo, 1920; Goulden, 1968; Smirnov, 1976; Elías-Gutiérrez \& Zamuriano-Claros, 1994; Alonso, 1996; Paggi, 1997; Elmoor-Loureiro et 
al., 2010) between the American and Old World morphotypes, and add some taxonomical remarks that should be considered for further descriptions of new species belonging to these species complexes. Specimens with genetic divergence lower than $3 \%$ do not present morphological differences, so we can conclude that BIN numberAAC3108, representing Moina americana Goulden, 1968 n. stat. is present in Canada, USA (from terra typica, near the original type locality, see specimens with Process ID: BCRUS111-10, BCRUS107-10, and BCRUS106-10 in BOLD), and is distributed in Mexico and Bolivia. The low variability of the American species, the high number of haplotypes (8 haplotypes) and the broad geographical area of distribution, shown by our results, indicates that this species is beginning an expansion that started less than 250000 years ago (according to Ratnasingham \& Hebert, 2007).

The high existent divergence between the populations in the Old World can be interpreted as a longer time of separation represented by the BIN numbers ACH4664 andACA1705 with a maximum divergence of $3.72 \%$. This divergence is also coincident with morphological traits as mentioned above.

The use of molecular markers helped us to delimitate species, but the sole use of these tools, will cause the loss of essential information (Will et al., 2005). The phenotypical plasticity present in different geographical areas for invertebrate evidence high cryptic speciation and not morphotypes or cosmopolitanism, as it has been considered (Alcántara-Rodríguez et al., 2012; Karanovic 2015; Lavinia et al., 2017).

In other regard, haplotypes shared between distant geographical sites evidence a recent translocation of both species, Moina macrocopa s.l. and Moina americana Goulden, 1968 n. stat., possibly due to human activities such as it has been documented several times for the European clade of this species and for other microinvertebrate taxa (Elías-Gutiérrez \& Zamuriano- Claros, 1994; Miracle et al., 2013; Vignatti et al., 2013; Montoliu et al., 2015) and also, due to biotic (birds) or/and abiotic factors. It is widely documented that cladocerans during the glaciations of Pleistocene survived in small isolated refugia during the Ice Age. Since the thaw, they colonized many new areas due to the ephippia stuck in the legs of birds (Adamowicz et al., 2002; Korovchinsky, 2006), and given their opportunistic and potentially invasive nature (Vignatti et al., 2013) they became common in new habitats or environments. In this regard, climate change drives birds to change their migration routes, and with them,

Table 5. Genetic diversity index and neutrality test (Fu \& Tajima's D) on the mitochondrial COI sequences of Moina macrocopa complex. $n$ : number of sequences; S: number of polymorphic sites; h: number of haplotypes; Hd: haplotype diversity; p: nucleotide diversity; k: average number of pairwise nucleotide differences. Tajima's D: A negative Tajima's D signifies an excess of low frequency polymorphisms relative to expectation. A positive Tajima's D signifies low levels of both low and high frequency polymorphisms. Statistical significance: Not significant, $P>0.1$. Índices de diversidad genética y test de neutralidad (Fu y Tajima's D) de las secuencias del gen mitocondrial COI del complejo Moina macrocopa. n: número de secuencias; S: número de sitios polimórficos; h: número de haplotipos; Hd: diversidad haplotipica; $p$ : diversidad nucleotídica; $k$ : número promedio de diferencias de nucleótidos por pares. Tajima's D: un valor negativo en el test significa un exceso de polimorfismos de baja frecuencia en relación con las expectativas un valor positivo en el test significa bajos niveles de polimorfismos de baja y alta frecuencia. Significancia estadística: No significante, $\mathrm{P}>0.1$.

\begin{tabular}{|c|c|c|c|c|c|c|c|c|c|c|}
\hline \multirow[b]{2}{*}{ EUROPE } & \multirow{2}{*}{$\frac{n}{28}$} & \multirow{2}{*}{$\frac{S}{19}$} & \multirow{2}{*}{$\frac{h}{8}$} & \multirow{2}{*}{$\frac{\mathrm{Hd}}{0.86}$} & \multirow{2}{*}{$\begin{array}{l}\pi \\
0.02506\end{array}$} & \multirow{2}{*}{$\frac{\mathbf{K}}{7.57}$} & \multicolumn{2}{|c|}{ Tajima's D (Significance) } & \multicolumn{2}{|c|}{ Fu \&Li (Significance) } \\
\hline & & & & & & & 1.57 & $P>0.10$ & 0.96 & $P>0.10$ \\
\hline ASIA & 4 & 1 & 2 & 0.5 & 0.00166 & 0.5 & -0.5 & $P>0.10$ & 1.44 & $P>0.10$ \\
\hline AMERICA & 21 & 6 & 8 & 0.855 & 0.00760 & 2.286 & 0.18769 & $P>0.10$ & 0.18769 & $P>0.10$ \\
\hline TOTAL & 64 & 59 & 18 & 0.937 & 0.07934 & 24.04 & 2.28 & $P<0.5$ & & \\
\hline
\end{tabular}




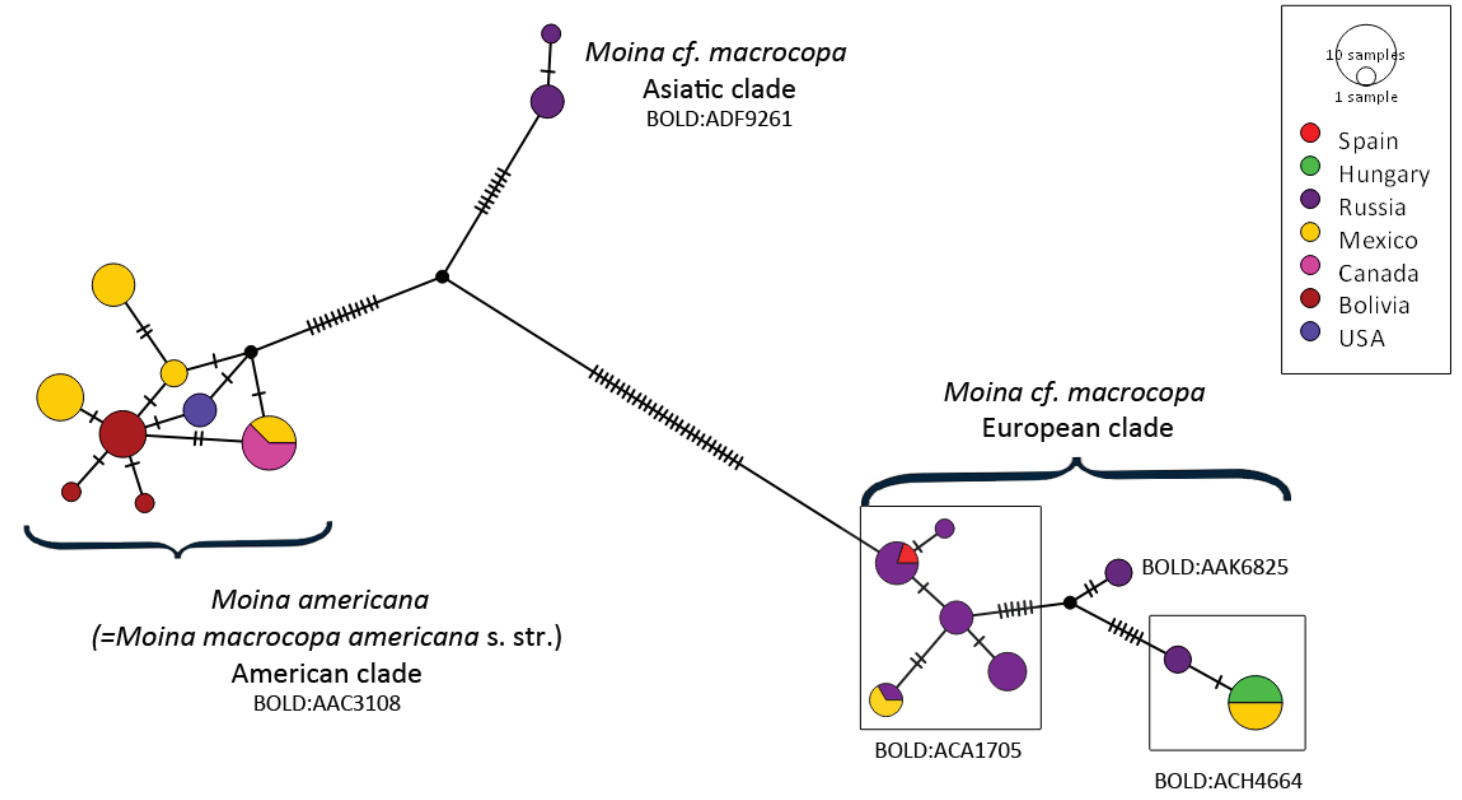

Figure 5. COI Haplotype network of Moina macrocopa complex. Each circle indicates a unique haplotype and variation in circle reflects the number of sequences assigned to haplotypes. Colors represent the countries of each haplotype. Red de haplotipos del gen COI del complejo Moina macrocopa. Cada círculo indica un haplotipo único y la variación en el tamaño del círculo refleja el número de secuencias asignadas a cada haplotipo. Los colores representan los países en donde se encuentra cada haplotipo.

Moina and other invertebrates will benefit to disperse to new warm regions, where before it was not possible to survive. Remark that the type locality of Moina americana n. stat., Cheyenne Bottoms, is the largest marsh in the interior of the United States, deeply modified by man, was designated a Wetland of International Importance in 1988 by the Ramsar Convention on Wetlands. The area is considered the most important shorebird migration point in the western hemisphere. Approximately 45 percent of the North American shorebird population stops at the Bottoms during spring migration so, it will be probably the reason to find the same haplotype of Moina americana $\mathrm{n}$. stat. distributed all over the American continent.

The proximity existent (morphological, genetical and geographical) between the different populations of the American clade and the lack of interest in this American species (because the European species is used as bioindicator and food for aquaculture) suggest that their distribution can be due to biotic or abiotic factors and not by an anthropogenic translocation.

Nevertheless, the Old World species found in
Calderitas (Mexico) seems to be a recent human mediated translocation owing to the little divergence intraspecific existent between the Mexican populations and the Europeans (ACH4664: 0.41 \% and ACA1705: 0.75\%). We hypothesize that a European student of Amphibia, who surveyed the ponds before us, introduced the resistant ephippia inadvertently with his net in search of tadpoles. Both species were found inhabiting in sympatry in two close, isolated temporary pools, with no fish. Otherwise, there is no explanation, because Moina macrocopa s.l. was included in a list of 94 potential invaders of inland waters, coastal and littoral lakes in Mexico (Okolodkov et al., 2007), but it has not been previously found in the tropics (Elías-Gutiérrez et al., 2001; Elías-Gutiérrez et al., 2008a; Elías-Gutiérrez et al., 2008b).

In this work, we increased the distributional area of Moina americana $\mathrm{n}$. stat. Its new range is from $58.77^{\circ} \mathrm{N}$ to $18.24^{\circ} \mathrm{S}$, but nowadays, only restricted to the American continent instead of just at the USA as Goulden (1968) stated.

Moina americana Goulden, 1968 n. stat. seems to prefer permanent water bodies, highly 
eutrophic and with an excess of food supply as Los Gringos dam and Texcoco Lake.

The use of an integrative approach to delimitate the species present in an ecosystem will facilitate the creation of zooplankton baselines that will permit more accurate biomonitoring and the early detection of changes in the environment.

\section{ACKNOWLEDGEMENTS}

This work forms part of the supported studies by Mexican Barcode of Life network, through the grants 194045, 194025 and 25085 and CONACyT through a National grant. Rosa Miracle ${ }^{\dagger}$ was the first promotor of this work, and kindly donated the specimens of M. macrocopa s.l. from Albufera de Valencia and gave facilities to sequence them in Servicios Generales from the Universitat de Valencia (Campus Burjassot). Brianne Jacobson let us know about the Moina in several pools from Calderitas town (Mexico). Thanks to Dr. Nir Stern who kindly review the English and enrich this paper. Finally, this study is part of Lucía Montoliu program to get the doctoral degree from Posgrado de Ciencias del Mar y Limnología (UNAM, Mexico). Part of SEM images were processed in a JEOL microscope Model JSM6010 Plus at Chetumal Unit of ECOSUR and part, in a JEOL microscope Model LB5900 in the Autonomous University of Aguascalientes by Araceli Adabache-Ortiz. Special thanks to Dr. Rosa Miracle ${ }^{\dagger}$ for all her contributions to the world of science, and specific for all the support I received from her, because without her this project would not have been possible.

\section{REFERENCES}

ADAMOWICZ, S. J., T. R., GREGORY, M. C. MARINONE \& P. D. N HEBERT. 2002. New insights into the distribution of polyploid Daphnia: the Holarctic revisited and Argentina explored., Molecular Ecology, 11 (7): 1209-1217. DOI: 10.1046/j.1365-294X. 2002.01517.x

ALCÁNTARA-RODRÍGUEZ, J. A., J CIROSPÉREZ, E. ORTEGA-MAYAGOITIA, C. R. SERRANIA-SOTO, \& E. PIEDRA-IBARRA, E. 2012. Local adaptation in populations of a Brachionus group plicatilis cryptic species inhabiting three deep crater lakes in Central Mexico, Freshwater Biology, 57 (4): 728-740. DOI: $10.1111 / \mathrm{j} .1365-2427.2012$. 02738.x

ALCOCER, J. \& BERNAL-BROOKS, F. W. 2010. Limnology in Mexico, Hydrobiologia, 644 (1): 15-68. DOI: $10.1007 / \mathrm{s} 10750-010-$ 0211-1

ALONSO, M. 1996. Fauna Iberica vol. 7. Crustacea, Branchiopoda. 1st edn. Edited by M. Ramos Sánchez, X. Alba, Tercedor, J. Gosálbez i Noguer, A. Guerra Sierra, E. Macpherson Mayol, F. Martín Piera, J. Serrano Marino, \& J. González Templado. Madrid: Museo Nacional de Ciencias Naturales, Consejo Superior de Investigaciones Científicas - CSIC.

ÁLVAREZ-CASTAÑEDA, S. T., C. LORENZO, E. RIOS, P. CORTÉS-CALVA, M. ELÍAS-GUTIÉRREZ, J. ORTEGA \& F. A. CERVANTES. 2012. DNA Barcoding of Mammals in Mexico?: Implications for Biodiversity, The Open Zoology Journal, 5 (1-M4): $18-26$.

ARÉVALO, C. 1920. Notas hidrobiológicas, in Boletín de la Real Sociedad Española de Historia Natural. Tomo XX 163-168. Available at: http://www.biodiversitylibrary.org/ item $/ 142519$

ASHFAQ, M., S. PROSSER, S. NASIR, M. MASOOD, S. RATNASINGHAM \& P. D. N. HEBERT. 2015. High diversity and rapid diversification in the head louse, Pediculus humanus (Pediculidae: Phthiraptera). Scientific Reports. Nature Publishing Group, 5: 14188. DOI: $10.1038 /$ srep 14188

AUDZIJONYTE, A. \& R. VÄINÖLÄ. 2006. Phylogeographic analyses of a circumarctic coastal and a boreal lacustrine mysid crustacean, and evidence of fast postglacial mtDNA rates. Molecular Ecology, 15 (11): 3287-3301. DOI: 10.1111/j.1365-294X.2006. 02998.x

BEKKER, E. I., D. P. KARABANOV,Y. R. GALIMOV \& A. A. KOTOV. 2016. DNA Barcoding reveals high cryptic diversity in the North Eurasian Moina Species (Crustacea: Cladocera). Plos One, 11 (8): e0161737. DOI: 10.1371/journal.pone.0161737 
BREHM, V. 1936. "Report on Cladocera." Mem. Connecticut. Acad. 10: pp. 283-297.

CHERTOPRUD, E. S., A. Y. SINEV \& I. DIMANTE-DEIMANTOVICA. 2017. Fauna of Cladocera and Copepoda from Xinjiang Uyghur autonomous region (China). Zootaxa, 4258 (6): 561-573. DOI: 10.11646/zootaxa. 4258.6.5

CLEMENT, M., Q. SNELL, P. WALKER, D. POSADA \& K. CRANDALL. 2002. TCS: Estimating gene genealogies. Parallel and Distributed Processing Symposium, International Proceedings, 2: 184.

DADAY, J. 1883. "Adatok a Szent-Anna es Mohosto fauna- janak ismeretehez." Orvos-termes., Ertesito 5.

DASMAHAPATRA, K. K., M. ELIAS, R. I. HILL, J. I. HOFFMAN \& J. MALLET. 2010. Mitochondrial DNA barcoding detects some species that are real, and some that are not. Molecular Ecology Resources, 10 (2): 264-273. DOI: 10.1111/j.1755-0998.2009. 02763.x

DAYRAT, B. 2005. Towards integrative taxonomy, Biological Journal of the Linnean Society, 85 (3): 407-415. DOI: 10.1111/j.1095-8312. 2005.00503.x

ELÍAS-GUTIÉRREZ, M. \& R. ZAMURIANOCLAROS. 1994. Primer registro de Moina macrocopa (Daphniiformes: Moinidae) en Bolivia. Revista de Biología Tropical, 42 (1-2): 381.

ELÍAS-GUTIÉRREZ, M. 1995. Notas sobre los cladóceros de embalses a gran altitud en el Estado de México, México. Anales de la Escuela Nacional de Ciencias Biológicas, 40: 197-214.

ELÍAS-GUTIÉRREZ, M., N. N. SMIRNOV, E. SUÁREZ-MORALES \& N. DIMASFLORES. 2001. New and little known cladocerans (Crustacea : Anomopoda) from southeastern Mexico. Hydrobiologia, 442: 41-54.

ELÍAS-GUTIÉRREZ， M., F. MARTÍNEZ-JERÓNIMO, N. V. IVANOVA, M. VALDEZ-MORENO \& P. D. N. HEBERT. 2008a. DNA barcodes for Cladocera and Copepoda from Mexico and Guatemala, highlights and new discoveries. Zootaxa, 1839: 1-42.
ELÍAS-GUTIÉRREZ， M., E. SUÁREZ-MORALES, M. A. GUTIÉRREZ-AGUIRRE, M. SILVA-BRIANO, J. G. GRANADOSRAMIREZ. \& T. GARFIAS-ESPEJO. 2008b. Guía ilustrada de los microcrustáceos (Cladocera y Copepoda) de las aguas continentales de México. 1st edn. Edited by U. N. A. de México. Mexico.

ELMOOR-LOUREIRO, L. M. A., J. SANTANGELO,R., P. M. LOPES \& R. L. BOZELLI. 2010. A new report of Moina macrocopa (Straus, 1820) (Cladocera, Anomopoda) in South America. Braz. J. Biol, 70 (1): 225-226. DOI: $10.1590 / \mathrm{S} 1519-69842010000100031$

FREY, D. G. 1980. On the plurality of Chydorus sphaericus (0. F. Muller) (Cladocera, Chydoridae), and designation of a neotype from Sjaelso, Denmark. Hydrobiologia, 69: 83-123.

FREY, D. G. 1987. The taxonomy and biogeography of the Cladocera, Hydrobiologia, 145: 5-17.

GHAOUACI, S., M. AMAROUAYACHE, A. Y. SINEV, N. M. KOROVCHINSKY \& A. A. KOTOV. 2018. An annotated checklist of the Algerian Cladocera (Crustacea: Branchiopoda). Zootaxa, 4377 (3): 412-430. DOI: 10.11646/zootaxa.4377.3.5

GOULDEN, C. E. 1968. The Systematics and Evolution of the Moinidae. Transactions of the American Philosophical Society, 58 (6): 1-101.

GUTIÉRREZ-AGUIRRE, M. A., A. CERVANTEZ-MARTÍNEZ \& M. ELÍAS-GUTIÉRREZ. 2014. An example of how Barcodes can clarafy cryptic species: The case of the calanoid copepod Mastigodiaptomus alburquerquensis (Herrick). PLoS ONE, 9 (1): e85019.

HEBERT, P. D. N., A. CYWINSKA, S. L. BALL \& J. R. DEWAARD. 2003a. Biological identifications through DNA barcodes. Proceedings of the Royal Society B: Biological Sciences, 270 (1512): 313-321. DOI: 10.1098/rspb. 2002.2218

HEBERT, P. D. N., S. RATNASINGHAM \& J. R. DEWAARD. 2003b. Barcoding animal life: cytochrome c oxidase subunit 1 divergences among closely related species. 
Proceedings of the Royal Society of London, 270 (September): 96-99. DOI: 10.1098/rsbl. 2003.0025

JÄCH, M. A. 2000. International Code of Zoological Nomenclature. 4th edn. Edited by T. N. H. Museum. London, UK: International Commission on Zoological Nomenclature. Available at: http://www.iczn.org/iczn/index.jsp.

JEFFERY, N. W., M. ELÍAS-GUTIÉRREZ \& S. J. ADAMOWICZ. 2011. Species diversity and phylogeographical affinities of the branchiopoda (crustacea) of Churchill, Manitoba, Canada. PLoS ONE, 6 (5): e18364. DOI: 10.1371/journal.pone.0018364

JOBLOT, M. 1754. Observations d'Histoire Naturelle, faites avec le microscope. Tome premier. Paris.

KAPLI, P., S. LUTTEROPP, J. ZHANG, K. KOBERT, P. PAVLIDIS, A. STAMATAKIS \& T. FLOURI. 2017. Multi-rate Poisson Tree Processes for single-locus species delimitation under Maximum Likelihood and Markov Chain Monte Carlo. Bioinformatics, 33 (January): 1630-1638. DOI: 10.1093/bioinformatics/btx025

KARANOVIC, I. 2015. Barcoding of Ancient Lake Ostracods (Crustacea) Reveals Cryptic Speciation with Extremely Low Distances. PloS One, 10 (3): 1-17. DOI: 10.5061/ dryad.332s6

KIMURA, M. 1980. A Simple Method for Estimating Evolutionary Rates of Base Substitutions Through Comparative Studies of Nucleotide Sequences. J. Mol. Evol, 16 (1330): 111-120. DOI: 10.1007/BF01731581

KOROVCHINSKY, N. M. 2006. The Cladocera (Crustacea: Branchiopoda) as a relict group. Zoological Journal of the Linnean Society, 147 (1): 109-124. DOI: 10.1111/j.1096-3642. 2006.00217.x

KOTOV, A. A., H. G. JEONG \& W. LEE. 2012. Cladocera (Crustacea: Branchiopoda) of the south-east of the Korean Peninsula, with twenty new records for Korea. Zootaxa, 90 (3368): 50-90.

LAVINIA, P. D., E. O.NÚÑEZ BUSTOS, C. KOPUCHIAN, D. A. LIJTMAER, N. C. GARCÍA, P. D. N. HEBERT \& P. L. TUBARO. 2017. Barcoding the butterflies of southern South America: Species delimitation efficacy, cryptic diversity and geographic patterns of divergence. PLoS ONE, 12 (10): e0186845. DOI: 10.1371/journal.pone.0186845 LEIGH, J. W. \& D. BRYANT. 2015. PopART: full-feature software for haplotype network construction. Methods in Ecology and Evolution, 6 (9): 1110-1116. Available at: http://popart.otago.ac.nz.

LIBRADO, P. \& J. ROZAS. 2009. DnaSP v5: A software for comprehensive analysis of DNA polymorphism data, Bioinformatics, 25 (11): 1451-1452. DOI: 10.1093/bioinformatics/ btp 187

LIMA, F. D., W. M. BERBEL-FILHO, T. S. LEITE, C. ROSAS. \& S. M. Q. LIMA. 2017. Occurrence of Octopus insularis Leite and Haimovici, 2008 in the Tropical Northwestern Atlantic and implications of species misidentification to octopus fisheries management. Marine Biodiversity, 47 (3): 723-734. DOI: 10.1007/s12526-017-0638-y

MACHIDA, R. J., M. U. MIYA, M. NISHIDA \& S. NISHIDA. 2004. Large-scale gene rearrangements in the mitochondrial genomes of two calanoid copepods Eucalanus bungii and Neocalanus cristatus (Crustacea), with notes on new versatile primers for the srRNA and COI genes. Gene, 332 (1-2): 71-78. DOI: 10.1016/j.gene.2004.01.019

MANGAS-RAMÍREZ, E., S. S. S. SARMA \& S. NANDINI. 2004. Recovery patterns of Moina macrocopa exposed previously to different concentrations of cadmium and methyl parathion: Life-table demography and population growth studies. Hydrobiologia, 526 (1 SPEC. ISS.): 255-265. DOI: 10.1023/B:HYDR. 0000041596.73437 .17

MIRACLE, M. R., V. ALEKSEEV, V. MONCHENKO, V. SENTANDREU, \& E. VICENTE. 2013. Molecular-genetic-based contribution to the taxonomy of the Acanthocyclops robustus group. Journal of Natural History, 47: (5-12): 863-888. DOI: 10.1080/00222933.2012.744432

MONTOLIU, L., M. R. MIRACLE, \& M. ELÍASGUTIÉRREZ. 2015. Using DNA barcodes to detect non-indigenous species?: the case of the Asian copepod Mesocyclops pehpeiensis 
$\mathrm{Hu}, 1943$ ( Cyclopidae ) in two regions of the world. Crustaceana, 88 (12-14): 1323-1338. DOI: $10.1163 / 15685403-00003500$

MUTANEN, M., S. M. KIVELÄ, R. A. VOS, C. DOORENWEERD, S. RATNASINGHAM, A. HAUSMANN, P. HUEMER, V. DINCA, E. J. VAN NIEUKERKEN, C. LOPEZVAAMONDE, R. VILA, L. AARVIK, T. DECAËNS, K. A. EFETOV, P. D. N. HEBERT, A. JOHNSEN, O. KARSHOLT, M. PENTINSAARI, R. ROUGERIE, A. SEGERER, G. TARMANN, R. ZAHIRI \& H. C. J. GODFRAY. 2016. Species-level paraand polyphyly in DNA barcode gene trees: Strong operational bias in European Lepidoptera. Systematic Biology, 65 (6): 1024-1040. DOI: 10.1093/sysbio/syw044

NANDINI, S., S. M. MAYELI \& SARMA, S. S. S. 2004. Effect of stress on the life table-demography of Moina macrocopa. Hydrobiologia, 526 (1): 245-254. DOI: 10.1023/B: HYDR.0000041597.96720.ff

NÉDLI, J., L. DE MEESTER, Á. MAJOR, K. SCHWENK, I. SZIVÁK \& L. FORRÓ. 2014. Salinity and depth as structuring factors of cryptic divergence in Moina brachiata (Crustacea: Cladocera). Fundamental and Applied Limnology, 184 (1): 69-85. DOI: 10.1127/1863-9135/2014/0462

OKOLODKOV, Y. B., R. BASTIDA-ZAVALA, A. L. IBÁÑEZ, J. W. CHAPMAN, E. SUÁREZ-MORALES, F. PEDROCHE \& F. J. GUTIÉRREZ-MENDIETA. 2007. Especies acuáticas no indígenas en México. Cienc. Mar., 11 (32): 29-37.

PAGGI, J. C. 1997. Moina macrocopa (Straus, 1820) (Branchiopoda, Anomopoda) in South America: an other case of species introduction?. Crustaceana, 70 (8): 886-893.

PETRUSEK, A. 2002. Moina (Crustacea : Anomopoda, Moinidae ) in the Czech Republic?: a review. Acta Soc. Zool. Bohem., 66: 213-220.

POSADA, D. \& T. BUCKLEY. 2004. Model selection and model averaging in phylogenetics: advantages of akaike information criterion and Bayesian approaches over Likelihood Ratio Tests. Systematic Biology, 53 (5): 793-808. DOI: 10.1080/10635150490522304 PROSSER, S., A. MARTÍNEZ-ARCE \& M.
ELÍAS-GUTIÉRREZ. 2013. A new set of primers for COI amplification from freshwater microcrustaceans. Molecular Ecology Resources, 13: 1151-1155. DOI: 10.1111/ 1755-0998.12132

PUILLANDRE, N., A. LAMBERT, S. BROUILLET \& G. ACHAZ. 2012. ABGD, Automatic Barcode Gap Discovery for primary species delimitation. Molecular Ecology, 21 (8): 1864-1877. DOI: 10.1111/j.1365-294X.2011. 05239.x

RATNASINGHAM, S. \& P. D. N. HEBERT 2007. BARCODING BOLD?: The Barcode of Life Data System (www.barcodinglife.org). Molecular Ecology Notes, 7: 355-364. DOI: 10.1111/j.1471-8286.2006.01678.x

RATNASINGHAM, S. \& P. D. N. HEBERT 2013. A DNA-based registry for all animal species: The Barcode Index Number (BIN) System. PLoS ONE, 8 (8): e66213. DOI: 10.1371/journal.pone.0066213

RIETZLER, A. C., P. M. MAIA-BARBOSA, M. M. RIBEIRO \& R. M. MENENDEZ. 2014. On the first record of the exotic Moina macrocopa (Straus, 1820) in Minas Gerais State, Brazil. Brazilian Journal of Biology, 74 (2): 518-520. DOI: 10.1590/1519-6984.14113

SMIRNOV, N. N. 1976. Macrothricidae I Moinidae fauni mira. Fauna SSSR, Rakoobraznie, 1 (3): 1-237.

STRAUS, H. E. 1819. Memoires sur les Daphina, de la classe des Crustacés. In: Memoires $d u$ Museum d'Histoire Naturelle, 5: 380-425.

STRAUS, H. E. 1820. Mémoire sur les Daphina, de la classe des Crustacés (Secondi Partie). In: Memoires du Muséum d'Histoire Naturelle, 6: 149-162.

TAMURA, K. 1992. Estimation of the number of nucleotide substitutions when there are strong transition-transversion and $\mathrm{G}+\mathrm{C}$-content biases. Molecular biology and evolution, 9 (4): 678-687.

TAMURA, K., G. STECHER, D. PETERSON, A. FILIPSKI \& S. KUMAR. 2013. MEGA6: Molecular Evolutionary Genetics Analysis Version 6.0. Molecular Biology and Evolution, 30:2725-2729. DOI: 10.1093/molbev/ mst197

TRIANTAFYLLIDIS, A., D. BOBORI, C. 
KOLIAMITRA, E. GBANDI, M. MPANTI, O. PETRIKI \& N. KARAISKOU. 2011. DNA barcoding analysis of fish species diversity in four north Greek lakes., Mitochondrial DNA, 22 Suppl 1 (October): 37-42. DOI: 10.3109/19401736.2010.542242

VALDEZ-MORENO, M., C. QUINTAL-LIZAMA, R. GÓMEZ-LOZANO \& M. del C. GARCÍA-RIVAS. 2012. Monitoring an alien invasion: DNA barcoding and the identification of lionfish and their prey on coral reefs of the Mexican Caribbean. PLoS ONE, 7 (6): 1-8. DOI: 10.1371/journal.pone.0036636.

VALDIVIA-VILLAR, R. S. 1988. Checklist of freshwater Cladocera from Perú. Amazoniana, 10: 283-297.

VIGNATTI, A. M., G. C. CABRERA, \& S. A. ECHANIZ. 2013. Distribution and biological aspects of the introduced species Moina macrocopa (Straus, 1820) (Crustacea, Cladocera) in the semi-arid central region of Argentina. Biota Neotropica, 13 (3): 86-92. DOI: $10.1590 / \mathrm{S} 1676-06032013000300011$

WILL, K. W., B. D. MISHLER, \& Q. D. WHEELER. 2005. The perils of dna barcoding and the need for integrative taxonomy. Systematic Biology, 54 (5): 844-851. DOI: $10.1080 / 10635150500354878$

Con el apoyo de:

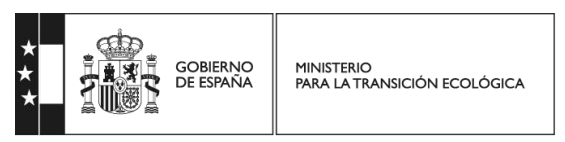

MINISTERIO
PARA LATRANSICIÓN ECOLOGICA

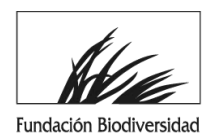

